\title{
تنزيه الله تعالى عند الزّمخشريّ والنّسفيّ: دراسة مقارنة
}

TRANSCENDENCE OF ALLAH ACCORDING TO ALZAMAKHSHARI AND AL-NASAFİ: A COMPARATIVE STUDY

\section{Syed Mohammad Hilmi Syed Abdul Rahman \& Mohd Khairul Naim Che Nordin}

Academy of Islamic Studies. University of Malaya. 50603. Kuala Lumpur. Malaysia.

Email: smhilmi@um.edu.my

\section{Khulasah}

Asas perbahasan berkenaan tanzih (mensucikan) Allah adalah penegasan kesempurnaan-Nya yang esa serta penolakan terhadap perkara yang tidak layak bagi kesucian-Nya. Allah Ta'ala telah menafikan penyerupaan setiap sesuatu dengan diri-Nya seperti yang disebut dalam surah al-Syura ayat 11 . Oleh itu tiada sesiapa atau sesuatu pun yang menyerupai atau menyamai-Nya. Sifat salbiyyah yang membawa makna menolak dan menafikan setiap kekurangan pada zat dan sifat Allah Ta'ala turut membawa maksud tanzih iaitu menyucikan-Nya. Ia menetapkan


(wahdāniyyah), berbezanya Allah dengan yang baharu (mukhālafah li al-hawādith) yang mana kesemua sifat ini menafikan penjisiman Allah serta sifat bertempatnya Allah. Makalah ini membahaskan konsep tanzìh Allah SWT menurut al-Zamakhsyari dan al-Nasafï. Kajian merumuskan tiada perselisihan di antara kedua-dua tokoh ini berkenaan konsep tanzìh melainkan pada aspek asas binaan konsep tersebut. Al-Zamakhsyari sebagai contoh menyucikan sifat-sifat Allah Ta`ala berasaskan sifat qadim, di mana sekiranya terdapat penyerupaan sesuatu dengan Allah maka keqadiman tersebut juga akan berbilangbilang dan ini menafikan prinsip ketauhidan Allah. Al-Nasafï seperti juga dengan pandangan al- 
Syed Mohammad Hilmi \& Mohd Khairul Naim, "Transcendence of Allah

According to al-Zamakhshari \& al-Nasafï," Afkār Vol. 19 Issue 1 (2017): $163-222$

Zamakhsari menyucikan Allah daripada penyerupaan dan persamaan dengan sesuatu yang baharu, namun beliau menetapkan wujudnya sifat-sifat qadim pada zat Allah. Bagi al-Nasafï, sifat-sifat yang qadim tidak membawa kepada berbilangnya keqadiman kerana sifat berbilang tersebut berdiri pada zat dan ia tidak memberi kesan pada zat Allah SWT yang esa.

Kata kunci: Tanzìh Allah Ta`ala, al-Zamakhsharī, al-Nasafi, sifat salbiyyah.

\begin{abstract}
The basis of discussion on the transcendence (tanzīh) of Allah is the assertion of His complete perfection and the rejection of anthropomorphism (tashbihh). Allah has denied the likeness of everything with Himself as mentioned in surah al-Shūrā verse 11. Therefore, no one or something resembles or equals Him and He is no way like anything created. One of the attributes of God, salbiyyah also indicates tanzih which means rejecting and denying any deficiencies with Allah. It establishes some of the attributes of God relating to the concept of tanzih which are eternity (qidām), everlastingness (baqā'), oneness (wahdāniyyah) and non-resemblance to the creation (mukhālafah li al-hawädith). All of these attributes deny the anthropomorphic depictions of Allah. This paper discusses the concept of tanzih according to alZamakhsyari and al-Nasafí. The study concludes that there is no disagreement between these two figures with regard to the concept of tanzih except on the basis of its conceptual aspects. Al-Zamakhsyari as an example transcend the attributes of Allah the Almighty based on His eternity. If there is a likeness of something with Allah then the eternity will be multiplied and this denies the principle of Tawhid. However, al-Nasafi sets forth the eternal attributes to the essences of Allah. For him, the attributes of eternity do not lead to the multiplicity of gods because the multitude of attributes are standing on
\end{abstract}


Syed Mohammad Hilmi \& Mohd Khairul Naim, "Transcendence of Allah According to al-Zamakhshari \& al-Nasafï," Afkār Vol. 19 Issue 1 (2017):

$163-222$

the essence and it does not affect the oneness of Allah.

Keywords: Tanzīh, al-Zamakhshari, al-Nasafī, salbiyyah.



إن تنزيه الله - تعالى - هو أوّل الكلام عند الحديث والبحث في الإلهيّات، لأن علم العقيدة وأصول الدين، وكل كلام المتكلمين عن صفات الله وأفعاله، وما يندرج تحت هذا الكلام، كل ذلك أساسه تأكيد الكمال لله - تعالى - وحده، وسلب ما لا يليق به - سبحانه -؛ فهناك من الأسماء والصفات ما لا يجوز اطلاقها على الله - تعالى -. فهو - تعالى - قد نفى التشبيه من كل وجهه، فلا أحد يشبهه -


ألسَّمِيعُ ألْبَصِيرُ [الشورى: 111]، فلا شبه، ولا نظير، ولا مثيل له تعالى . وقد نفت الآية الكريمة المشابهة بينه - تعالى - وبين غيره، وقد كرّرت كلمة التشبيه "مثل" - بعد كاف التشبيه - للتأكيد اللفظي، ولتأكيد نفي التماثل، أي: نفي الممثالة عن ذاته - تعالى -. فالله سبحانه - أتى بكلمة التشبيه وبكاف التشبيه زيادة في تأكيد النفي، لأنه كلما ازدادت أدوات التشبيه قلَّ الشبه، ولو كان هناك نسبة قليلة من الشبه لانتفت بقوله - تعالى -: لَيْسَ ، فالله - تعالى - منزه عن مشابهة خلقه في ذات أو صفة، فلا تشبيه ولا تمثيل، كما أن الآية 
Syed Mohammad Hilmi \& Mohd Khairul Naim, "Transcendence of Allah

According to al-Zamakhshari \& al-Nasafi,", Afkär Vol. 19 Issue 1 (2017):

$163-222$

تدلّ على التنزيه الكلي لأن الله - سبحانه - ذكر فيها لفظ "شَهْئه"




مشابهة أي شيء.

ووصفه - تعالى - لا يشبه وصف غيره بدليل قوله - تعالى -












هَلْ تَعْلَمُ لَهُ سَمَيَّا [مريم: 70]، أي: "هل تعلم له شبيها، هل تعلم له


يُساميه في صفات الكمال، وليس له نظير أو مثيل أو شبيه، بدليل

${ }^{1}$ Abū Ḥayyān, Muḥammad bin Yūsuf bin `Alì al-Andalusī, al-Bahrr alMuhịt fì al-Tafsìir, ed. Șidqi Muhammad Jamīl (Beirut: Dār al-Fikr, 1420H), 6:549.

${ }^{2}$ Ibn `Ādil al-Hanbali, Sirāj al-Dīn 'Umar bin `Ali al-Dimasyqī alNu`mānī, al-Bāb fī 'Ulūm al-Kitāb, ed. 'Ādil Ahmad 'Abd alMawjūd and `Alì Muhammad Mu`awwiḍ (Beirut: Dār al-Kutub al'Ilmiyyah, 1998), 12:96.

3 Muhammad Mutawalli al-Sha rāwī, Tafsīr al-Sha 'rāwì al-Khawāṭir (n.p: Muțābi’ Akhbār al-Yawm, 1997), 15:9148. 
Syed Mohammad Hilmi \& Mohd Khairul Naim, "Transcendence of Allah According to al-Zamakhshari \& al-Nasafï," Afkār Vol. 19 Issue 1 (2017):



فالصفات السلبيّة والتي تعني سلب كل نقصٍ حول ذات الله

أو صفاته، أو نفي النقص عنه - سبحانه -هو المراد بالتنزيه، لكن

المشبّهة والمحسّمة حين قاسوا الخالق على المخلوق، وشبّهُوا الخالق بالمخلوق فقد خالفوا الشرع والعقل في ذلك، كقولمم: يد الله كأيدينا، أو قولمم بجلوس الله - تعالى - على العرش كجلوس المخلوقين، واستقراره وما إلى ذلك من صفات لا يجوز لأحدٍ أن يصف الله تعالى - كما إلا بما وصف هو به نفسه من غير تشبيه ولا تمثيل.


للحوادث التي فيها إبطال الجمسميّة له، ونفي المكانيّة عنه وغيرها، هو


تركت لما فصلاً خاصَّا لارتباطها الوثيق بالتنزيه.

$$
\text { تنزيه الله - تعالى - عند الزّمخشريّ }
$$

لقد نزّت المعتزلة الله - تعالى - عن المشاهة والمماثلة: بالدلائل والبراهين العقليّة قبل النقليّة وذلك ردًا على المشبّهة والبمسّمة وأفرط

${ }^{4}$ Abū Ja far Muhammad bin Jarìr al-Ṭabarì, Jāmi`al-Bayān 'an Ta'wīl āy al-Qur'ān, ed. `Abd Allāh bin `Abd al-Muhssin al-Turkì (Cairo: Dār Hijr, 2001), 15:586. 
Syed Mohammad Hilmi \& Mohd Khairul Naim, "Transcendence of Allah

According to al-Zamakhshari \& al-Nasafï," Afkār Vol. 19 Issue 1 (2017):

بعضهم في نفي الصّفات ونفي ما أثبتته المشبّهة حتى وقعوا في


الباري بصفة يوصف بها خلقه لأن ذلك يقتضي تشبيهاً، فنفى كونه


خلقه بالقدرة والفعل والخنق 5".

أما عن الصّفات السلبيّة والتي تعني سلب ما لا يليق بذاته - تصني

تعالى - وهي الصّفات الواجبة له والتي تكلم فيها المتكلمون تنزيهاً له - سبحانه - والتي منها الوحدانيّة والقدم والبقاء، وفي مخالفته تعالى - للحوادث، والقيام بنفسه، فالإمام الزّخشريّ كلام فيه لا يكاد يختلف عما أتت به المعتزلة. فعندما تكلم الإمام عن الوحدانيّة قال بأن وححانيّة الله ومعرفته لا تأتي إلا عن طريق العقل وأما النقل فهو تأكيد لأدلة العقل






رسول الله - صلى الله عليه وسلم - عن عبادة الأوثان بأدلة العقل

${ }^{5}$ Muḥammad bin `Abd al-Karīm al-Shahrastānī, al-Milal wa al-Nihal, ed. Muhammad Sayyid Kaylānì (Beirut: Dār al-Ma`rifah, 1404H), $1: 86$. 
Syed Mohammad Hilmi \& Mohd Khairul Naim, "Transcendence of Allah According to al-Zamakhshari \& al-Nasafï," Afkār Vol. 19 Issue 1 (2017):

$163-222$

حتى جاءته البينات من ربه؟ قلت : بلى ولكن البينات لما كانت مقوية لأدلة العقل ومؤكدة لما ومضمنة ذكرها نهو قوله - تعالى-:


[الصافات: 90 - 97 9 وأشباه ذلك من التنبيه على أدلة العقل كان ذكر البينات ذكر الأدلة العقل والسمع جميعاً، وإنما ذكر ما يدلّ على الأمرين جميعاً، لأن ذكر تناصر الأدلة؛ أدلة العقل، وأدلة السمع أقوى في إبطال مذهبهم، وإن كانت أدلة العقل وحدها كافية6". وتفسير الزّخشريّ لهذه الآية بأن معرفة الله - تعالى لـه ووحدانيته واستحالة أن تكون الأصنام آلهة مستفادة من أدلة العقول فقط، أو أن أدلة العقل كافية في ذلك قول غير صحيح، وذلك لأن اعتقاده أن هذه الأمور لا تعلم إلى بالعقل المحض فقط، أما السمع فهو إنما يدلّ بطريق الخبر الصادق، وخبر الصادق الذي هو النبي لا يعلم صدقه إلا بالعقل، وأهل السيّنة لا يرون كما يرى. فرأي الزّخشريّ أن العقل حاكم مستقل، يمكن الاستغناء بحكمه دون الشرع، مع أنه - كما قال الغامدي - "عند أهل الحق لا منافاة بين العقل والنقل أصلاً، ولا تضخيم للعقل في جانب وإهداره في جانب،

\footnotetext{
${ }^{6}$ Abū al-Qāsim Mạmmūd bin 'Umar al-Khawārizmī al-Zamakhsharí, al-Kashshāf 'an Haqū' iq al-Tanzīl wa 'Uyūn al-Aqāwīl fī Wujūh alTa'wìl, ed. `Abd al-Razzaq al-Mahdi, vol. 3 (Dar al-Kitab al-'Arabi, 1407H), 4:182.
} 
Syed Mohammad Hilmi \& Mohd Khairul Naim, "Transcendence of Allah

According to al-Zamakhshari \& al-Nasafï," Afkār Vol. 19 Issue 1 (2017):

$163-222$

وليس هناك أصل من أصول العقيدة يستقلّ العقل بإثباته أبدًا، كما





ولذلك أضاف الغامدي وهو يرد على الزّخشريّ، ومن نحا



المخبر لا يعلم إلا بالأصول والمقدمات العقليّة فقد غلط في ذلك

غلطاً عظيمًا، بل ضلالاً مبينًا، حيث ظن أن إن دلالة الكتاب والسنة إنما هي بطريق الخبر المخرد، بل الأمر ما عليه سلف الأمة، أهل العلم والإيمان من أن الله - سبحانه وتعالى - بيّن من الأدلة العقليّة التي يحتاج اليها في العلم بتلك المطالب الإلهية ما لا يقدر أحد من هؤلاء قدره، وغهاية ما يذكرونه جاء القرآن بخلاصته على أحسن وجه، فإن إن إنها كثيراً مما دل عليه السمع يعلم بالعقل أيضا، والقرآن يبيّن ما يستدل به العقل ويرشد إليه وينبّه عليه، كما ذكر ذلك في غير موضع فإنه سبحانه وتعالى - يبيّن من الآيات الدالة عليه، وعلى وحدانيته وقدرته


دل على نبوة أنبيائه، وما دل على المعاد وإمكانه 8.".

\footnotetext{
${ }^{7}$ Ṣāliḥ bin Gharm Allāh al-Ghāmidì, al-Masā'il al-'Itizāliyyah fỉ Tafsìr al-Kashshāf li al-Zamakhshari fï Daw' mā Warad fï Kitāb al-Intișāf li Ibn al-Munayyir (Lahore: Dār al-Andalus, n.d), 2:896.

${ }^{8}$ Ibid.
} 
Syed Mohammad Hilmi \& Mohd Khairul Naim, "Transcendence of Allah According to al-Zamakhshari \& al-Nasafï," Afkār Vol. 19 Issue 1 (2017):

فالعقل البمرّد وإن أمكنه إدراك بعض الحقائق ومعرفة حسن بعض الأشياء وقبحها بطريق الإجمال، إلا أنه يقف عاجزاً عند كثير من تفاصيل هذه الأمور الخارجة عن قدرته وإحاطته كتفاصيل أسماء الله وصفاته وما يجب له من ذلك، وأحوال الموت والآخرة، وغيرها، بل إنّ العقل لا سبيل له إلى اليقين في عامة المطالب الإلهية بدون النقل كما اعترف بذلك أساطين ونخول علماء الكلام . ورأيي أن أدلة العقل قد يتوصّل بها إلى وحدانيّة الله - سبحانه وتعالى - والعلم به وبكونه الخالق إلى غير ذلك، ولكن لا يقال: إفا سنا وحدها فحسب كافية على تفسير وبيان كل ما أتى به الشرع، فالعقل عند الإمام الزّخشريّ هو الفيصل الحاكم في كون تحريم عبادة غير الله - تعالى - آتية من الله سبحانه قبل أن تأتي البينات من الله عن لهن طريق الرسل، قوله هذا مبني على أساس قاعدة التحسين والتقبيح عند


بينت الآيات من حيث معقولية الأدلة العقليّة ومعرفتها بمقادير الثواب والعقاب، فالأدلة العقليّة لا تتوصل إلى بيان ذلك. ويذهب الإمام الزّخشريّ إلى أن مهمة الرسل ليست إلا تنبيهاً للعقل من غفلته، وتعليم الشرائع، وهم بذلك متمّمون لحجّة العقل حيث

${ }^{9}$ Ibid., 2:896-897. 
Syed Mohammad Hilmi \& Mohd Khairul Naim, "Transcendence of Allah According to al-Zamakhshari \& al-Nasafî," Afkār Vol. 19 Issue 1 (2017):




يكون للناس على الله حجة قبل الرسل، وهم محجوجون بما نصبه الله


يتوصلوا إلى المعرفة إلا بالنظر في تلك الأدلة ، ولا عرف أهم رسل الله


النظر، كما ترى علماء أهل العدل والتوحيد مع تبليغ ما حملوه من تفضيل أمور الدين وبيان أحوال التكليف وتعليم الشرائع ، فكان إرساهم إزاحة للعلة وتتميماً لإلزام الحجة، لئلا يقولوا: لولا أرسلت إلينا رسولا فيوقظنا من سنة الغفلة، وينبهنا لما وجب الانتباه له 10".






قبل محمد صلى الله عليه وسلم. فإن قلت: فإذا لم يأقم نذير لم تقم عليهم حجة. قلت: أما قيام الحجة بالشرائع التي لا يدرك علمها إلا بالرسل فلا، وأما قيامها بمعرفة الله وتوحيده وحكمته فنعم، لأن أدلة العقل الموصلة إلى ذلك معهم في كل زمان 11".

${ }^{10}$ Al-Zamakhshari, al-Kashshāf, 1:625.

${ }^{11}$ Ibid., 3:514. 
Syed Mohammad Hilmi \& Mohd Khairul Naim, "Transcendence of Allah According to al-Zamakhshari \& al-Nasafï," Afkār Vol. 19 Issue 1 (2017):

فعند الإمام الزّخشريّ أن الشرائع التي لا يدرك علمها إلا بالرسل لا تقوم الحجة بها إلا بإرسال الرسل، أما معرفة الله وتوحيده وحكمته، فالحجة قائمة بها لأن أدلة العقل موصولة إليها وهذا ما دل عليه تفسيره لهذه الآية الكريمة. والإمام الزّخشريّ في تفسيره للآيات الواردة في الوحدانيّة يهتمّ بأن يفسّرها ويحللها لغويَّا ونخويَّا، وأحياناً بلاغيَّا ليبيّن ما تدلّ عليه معاني هذه الآيات، واستكشاف دقة الأسلوب القرآني وروعته في








عليه النص، ويقول: وصفت آلهة ب(إلا) كما توصف ب(غير)، لو قيل آلهة غير الله. فإن قلت: ما منعك من الرفع على البدل؟ قلت: لأن (لو) بمنزلة (إن) في أن الكلام معه موجب، والبدل لا يسوغ إلا في


أمْرَأَتَكَ [هود: 1ر]]، وذلك لأن أعمّ العام يصح نفيه، ولا يصح إيبابه. والمعنى : لو كان يتولاهما ويدبّر أمرهما آلهة شتى غير الواحد


Ṣābūnī, 2003), 2:263. 
Syed Mohammad Hilmi \& Mohd Khairul Naim, "Transcendence of Allah According to al-Zamakhshari \& al-Nasafï," Afkār Vol. 19 Issue 1 (2017): $163-222$

الذي هو فاطرهما لفسدتا. وفيه دلالة على أمرين، أحدهما: وجوب أن لا يكون مدبّرها إلا واحداً. والثاني: أن لا يكون ذلك الواحد إلا إيّاه وحده، لقوله: إِلَّا أللَّهُ. فإن قلت: لمُ وجب الأمران؟ قلت: لعِلمنا أن الرعية تفسد بتدبير الملكيْن لما يحدث بينهما من التغالب، والتناكر، والاختلاف.... وأما طريقة التمانع فللمتكلمين فيها بحاول وطراد، ولأن هذه الأفعال محتاجة إلى تلك الذات المتميزة بتلك الصّفات حتى تثبت وتستقر .

والظاهر من تفسير الإمام الزّخشريّ لهذه الآية زيادة على ما قاله الدكتور عبد العزيز ، أن الإمام الزّخشريّ لم يبْدِ رأيه في دليل التمانع الذي ذهب إليه المتكلمون وجعلوه دليلاً على توحيد الربوبية، وأن الرسل جاءت للدعوة إلى توحيد الربوبية. مع أن الرسل والكتب السماويّة لم تأتي أوّلاً إلا لتثبيت توحيد الألوهية قبل الربوبية الذي هو متضمن توحيد الربوبية، فالآية إنما دلت على توحيد الألوهية بدليل


فمشركو العرب كانوا يثبتون الربوبية لله - تعالى - ويشركون في الألوهية، وهم من نزل فيهم القرآن، وكذلك قوله - تعالى -: لَفَسَََتَا: فالسماوات والأرض لا تفسدا إلا بعد وجودهما، ودليل التمانع قائم على أساس عدم تكوينهما ووجودهما، والآية التي تصحّ 
Syed Mohammad Hilmi \& Mohd Khairul Naim, "Transcendence of Allah

According to al-Zamakhshari \& al-Nasafï," Afkār Vol. 19 Issue 1 (2017):

أن تكون دليل تمانع في الربوبية هي قوله - تعالى -: مَا أَتَّنَ آللَّلُ











والذي يراه الإمام السّكوني في تفسير الإمام الزّخشريّ لهذه الآية، وقوله: "وأما طريقة التمانع فللمتكلمين فيهما بتحاول وطراد". أن هذا القول من الإمام الزّخشريّ حيدة اعتزالية كما هو مذهب المعتزلة عن دلالة التمانع لأجل قواعد مذهبهم في اعتقاد خلق أفعالهم، ويلزم تمانع العبد مع ربه زمان خلقه لفعله، وعندهم أراد الله






الحديث عن تنزيه الله عند المعتزلة. شأنه في ذلك شأن باقي علماء الماتريديّة، والأشاعرة، والفرق الأخرى التي اتفقت معهم في إثبات

${ }^{13}$ Abū `Ali `Umar bin Muhammad al-Maghribi al-Māliki al-Sakūni, $a l$ Tamyìz limā Awda'hu al-Zamakhsharì min al-'Itizāl fi Tafsìr alKitāb al-`Aziz, ed. al-Sayyid Yūsuf Aḥmad (Beirut: Dār al-Kutub al'Ilmiyyah, 2005), 2:424. 
Syed Mohammad Hilmi \& Mohd Khairul Naim, "Transcendence of Allah

According to al-Zamakhshari \& al-Nasafï," Afkār Vol. 19 Issue 1 (2017):

الوحدانيّة لله تعالى. فهو يقول في تفسيره لقوله - تعالى - : قُُلْ هُوَ





والإمام الزّخشريّ يطلق كلمة (التخييل) عند تفسيره لآية

الميثاق الذي أخذه الله على ذريّة آدم ويعتبرها دليلاً على ربوبيّة الله ووحدانيّه فالله - تعالى - قد أخذ الميثاق من ظهر آدم ومن بني ذريته من ظهورهم دليلاً شاهداً على أنفسهم بأنه هو خالقهم








والتخييل! ومعنى ذلك أنه نصب لهم الأدلة على ربوبيته ووحدانيته، وشهدت بها عقولهم وبصائرهم التي ركبها فيهم، وجعلها بميّزة بين الضلالة والهدى، فكأنه أشهدهم على أنفسهم وقرهم وقال لهم: ألست بربكم؟ وكأفم قالوا: بلى أنت ربنا، شهدنا على أنفسنا،


لام الله تعالى ورسوله عليه السلام، وفي كلام العرب 15".

${ }^{14}$ Al-Zamakhshari, al-Kashshāf, 4:823.

${ }^{15}$ Ibid., 2:166. 
Syed Mohammad Hilmi \& Mohd Khairul Naim, "Transcendence of Allah According to al-Zamakhshari \& al-Nasafï," Afkār Vol. 19 Issue 1 (2017):

فإطلاق التخييل على كلام الله - تعالى - لم يأت به السمع والشرع، ولكنه أتى بإطلاق التمثيل فهذه اللفظة أنكرها البعض على الإمام الزّخشريّ حيث يقول ابن المنيَيّر: "إطلاق التمثيل أحسن، وقد ورد الشرع به. وأما إطلاقه التخييل على كلام الله تعالى فمردود، ولم يرد به سمع، وقد كثر إنكارنا عليه لهذه اللفظة. ثم إن القاعدة مستقرة على أن الظاهر ما لم يخالف المعقول يجب إقراره على ما هو عليه، فلذلك أقرّه الأكثرون على ظاهره وحقيقته، ولم يجعلوه مثالا، وأما كيفية الإخراج والمخاطبة فالله أعلم بذلك 16". والذي يراه الغامدي في تفسير الآية أن الله أخرج من أصلاب بني آدم ذريتهم، وجعلهم يتناسلون ويتوالدون قرناً بعد قرن، وقد أشهدهم على أنفسهم وقرّرهم بإثبات الربوبية والعبودية له بما أودعه في فطرهم 17 وليس بين الغامدي والزّخشريّ خلافاً في تفسير قوله تعالى:


الزّخشريّ حمل الآية على التمثيل، وفي هذا يقول صاحب تفسير آيات العقيدة: كما "وجد من المفسرين من حمل الآية على التمثيل

\footnotetext{
${ }^{16}$ Ibn al-Munayyir, al-Intișāf fïmā Tadammanuhu al-Kashshāf min alI'tizāl (Hāshiyah `ala al-Kashshāf) (Beirut: Dār al-Kitāb al-'Arabī, 1407H), 2:166.

${ }^{17}$ Al-Ghāmidī, al-Masā'il al-I tizāliyyah, 1:510.
} 
Syed Mohammad Hilmi \& Mohd Khairul Naim, "Transcendence of Allah

According to al-Zamakhshari \& al-Nasafi," Afkār Vol. 19 Issue 1 (2017):

كالزّخشريّ، ومن تبعه كالقاضي البيضاوي وغيره، ورأى أن معنى الآية أنه - تعالى -: نصب لهم الأدلة على ربوبيته ووحدانيته وشهدت بها عقولمم وبصائرهم التي ركبها فيهم، وجعلها مميزة بين الضلالة والهدى، فكأنه أشهدهم على أنفسهم وقررهم، وأن المقصود : بأخذ ذرياهم من ظهورهم وإخراجهم من أصلاً كهم نسلاً وأشهادهم على أنفسهم بذلك 18".

وقول الإمام الزّخشريّ هذا يتفق مع اختيار ابن كثير في تفسيره

حينما يقول: "وإليه مال الزّخشريّ، فإنه قال: فإن قلت: فما المراد بعهد الله؟ قلت: ما ركز في عقولمم من الحجة على التوحيد، كأنه أمر









غير أن الإمام السكوني يذهب إلى القول بأن في كلام وتفسير الإمام الزّخشريّ اعتزال لقول الإمام الزّخشريّ: إن ذلك على وجهه





${ }^{19}$ Abū al-Fidā' Ismāàil bin 'Umar bin Kathỉr al-Bașrī al-Dimashqi, Tafsìr al-Qur'ān al- 'Azìim, ed. Sāmī bin Muḥammad Salāmah, 2nd edition (Riyādh: Dār Țayyibah, 1999), 1:210. 
Syed Mohammad Hilmi \& Mohd Khairul Naim, "Transcendence of Allah

According to al-Zamakhshari \& al-Nasafï," Afkār Vol. 19 Issue 1 (2017):

عليه الآية، وتنكر الحديث الصحيح المفسر لمذه الآية، وهو ذرّ الذرية من ظهر آدم كأمثال الذر مع أن جواز ذلك معلوم قطعاً .20.

وي المنهاج ذكر الزّخشريّ الدليل على أن الله - تعالى - فرد لا ثاني له، بأن "إثبات إلهين قديمين متساويين محال، وذلك أن الاثنين إما غيران متباينان بالاختلاف: كالجسم والعرض أو بالتضاد: كالسواد والبياض، وإما مثلان متباينان بالصفة أو بالمكان أو بالزمان،

$$
\text { وكل ذلك ممتنع فوجبت الوحدانية } 21 .
$$

أما الصّفات الخبرية التي توهم المكانيّة لله - تعالى - ومشاهمة

المخلوق: كالاستواء، واليدين، والوجه، فالإمام الزّخشريّ قد أوّلها بما يقتضيه التنزيه، ونفي التشبيه، فهو يتأوّل قوله - تعالى -: أرَّمْنُُ







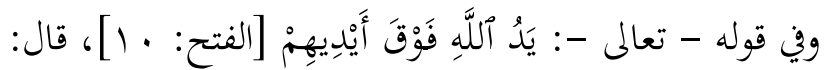
يريد أن يد رسول الله التي تعلو أيدى المبايعين: هي يد الله، والله

${ }^{20}$ al-Sakūni, al-Tamyiz, 2:268-269.

${ }^{21}$ Abū al-Qāsim Maḥmūd bin 'Umar al-Zamakhshari, Kitāb al-Minhāj fì Ușūl al-Dìn, ed. Sābīnā (Beirut: al-Dār al-'Ulūm al-'Arabiyyah, n.d.), 25.

${ }^{22}$ Al-Zamakhshari, al-Kashshāf, 3:54 and 4:739.

${ }^{23}$ Ibid., 4:445. 
Syed Mohammad Hilmi \& Mohd Khairul Naim, "Transcendence of Allah

According to al-Zamakhshari \& al-Nasafî," Afkār Vol. 19 Issue 1 (2017):

تعالى منزه عن الجوارح وعن صفات الأجسام، وإنما المعنى: تقرير أن عقد الميثاق مع الرسول كعقده مع الله من غير تفاوت بينهما، كقوله


الصّفات التي أثبتها المشبّهة صفات قائمة بالمخلوقات، والله لا يشابه خلقه فيؤدي ذلك إلى التشبيه أو التجسيم، فهذا محال عليه - تعالى -، فصفة السمع، والكالام، والبصر، والحياة، والاستواء، والتي تعني التعدّد في القدم، والحدوث منفية عند الإمام الزّخشريّ من باب تنزيهه - تعالى. - n - n

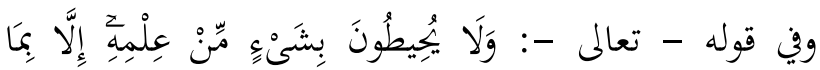

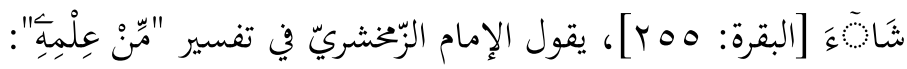
من معلوماته 25. ووافق رأيه ابن عطية، غير أنه علل ما ذهب إليه بد"أن علم الله تعالى الذي هو صفة ذاته لا يتبعّض، ومعنى الآية: لا معلوم لأحد إلا ما شاء الله أن يعلمه 26".

${ }^{24}$ Ibid., 4:337.

${ }^{25}$ Ibid., 1:328.

${ }^{26}$ Abū Muḥammad `Abd al-Haq bin Ghālib bin `Abd al-Raḥmān bin Tamām bin `Ațiyyah al-Andalusì al-Muhāribī, al-Muharrar al-Wajīz fī Tafsìr al-Kitāb al-`Azíz, ed. 'Abd al-Salām 'Abd al-Shāfī Muhammad, 1st edition (Beirut: Dār al-Kutub al-`Ilmiyyah, 1422H), $1: 341$. 
Syed Mohammad Hilmi \& Mohd Khairul Naim, "Transcendence of Allah According to al-Zamakhshari \& al-Nasafï," Afkār Vol. 19 Issue 1 (2017):

كما أن الإمام الزّخشريّ نفى صفتي السمع والعلم لأغما

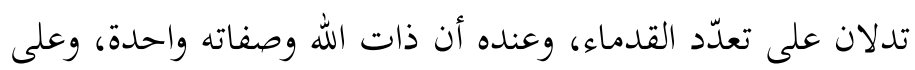

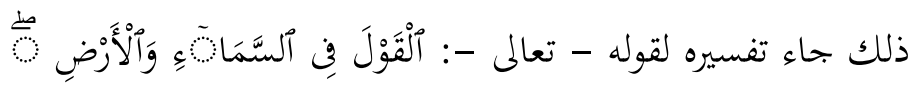

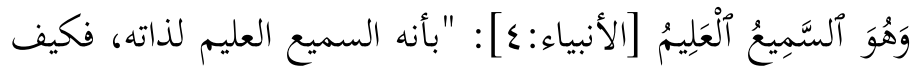
تخفى عليه خحافية 27.".

وعلى ذلك يعلق الغامدي بقوله :(بأنه السميع العليم لذاته) نفي صفتي السمع والعلم عن الله - تعالى - بناءً على قاعدة المعتزلة

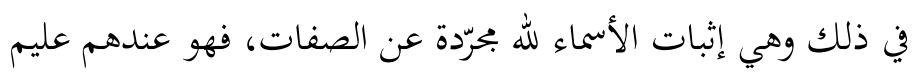

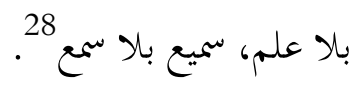
أما عن رؤية الله - تعالى -) إن جازت وحصلت، فإنها عند الإمام الزّخشريّ تعني أنه - سبحانه وتعالى - في جهة ومكان، وفي نظره أن الله - تعالى - منزه عن ذلك. فهو ينفي - نفيَ استحالة جواز رؤية الله - تعالى - بالأبصار في الآخرة كما ذهب المعتزلة.

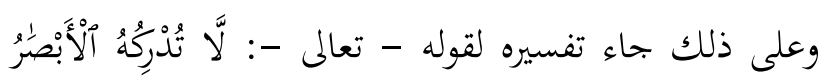



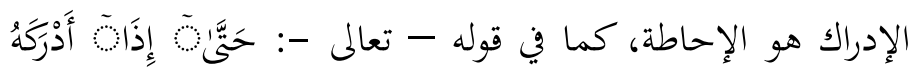



${ }^{27}$ Al-Zamakhshari, al-Kashshāf, 3:104.

${ }^{28}$ Al-Ghāmidī, al-Masā 'il al-I'tizâliyyah, 2:681. 
Syed Mohammad Hilmi \& Mohd Khairul Naim, "Transcendence of Allah According to al-Zamakhshari \& al-Nasafï," Afkār Vol. 19 Issue 1 (2017):

[الشعراء: آ]، أي: محاط بنا، وسأتناول مبحث رؤية الله في هذه الآية وغيرها وكيف فسّرها الإمام الزّخشريّ عند الحديث عنها في رؤية الله عند الإمام الزّخشريّ.

فالإمام الزّخشريّ ينفي أن يكون القديم جسماً أو عرضاً، أو إو في مكان، فهو يقول: "لو كان جسماً لكان محدثاً، لكونه غير منفكّ بك إن من الكون، وقد ثبت قدمه، ولكان فعل الجسم منه مستحيلاً، كما يستحيل من كل جسم. ولو كان عرضاً لوجب أن يحلّ الأجسام، ولو حلها لكان محدثاً مثلها أو هي قديمة مثله. وليس في مكان لأنه لو شغله لكان جسماً، ولو لم يشغله لم نفصل بين أن يكون فيه وبين أن لا يكون. ومعنى قولنا: هو في كل مكان، أنه عالم بما في كل مكان 29".

فالإمام الزّخشتريّ هنا يقرّر مبادئ المعتزلة في قولهم أن الصّفات أعراض لا تقوم إلا بجسم، وأنه لو قامت بالرب - سبحانه - الأفعال

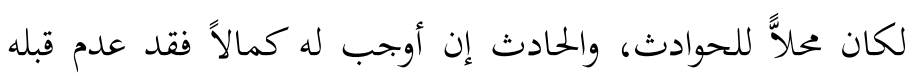
وهو نقص، وإن لم يوجب له كمالاً لمج يجب وصفه به، كما أنه في كإن كل مكان أي عالم بما في كل مكان. وفي تقريره هذا تنزيه لله - تعالى - حسب معتقده عن كل ما لا يليق به، فالله ليس كمثله شيء.

${ }^{29}$ Al-Zamakhshari, Kitāb al-Minhāj, 16. 
Syed Mohammad Hilmi \& Mohd Khairul Naim, "Transcendence of Allah According to al-Zamakhshari \& al-Nasafï," Afkār Vol. 19 Issue 1 (2017):

أما عن صفة القدم: فيقول الإمام الزّخشريّ: "فإن قلت: لمُ قلت إنه مختص بالقدم، والكلابية والأشعرية أثبتت ذواتا قديمة معه لِعري وهي معالٍ توجب صفاته؛ قدرة، وعلماً، وحياة، وإدراكاً، وقالوا: إن كلامه معنى قديم قائم بذاته، والثنوية أثبتت قديمين؛ وهي: النور والظلمة، ومن المجوس من يثبت مع قدم الله سبحانه قدم الشيطان: ويقولون هو خالق كل شر، وتقول النصارى: هو ثالث ثلاثة، وهو جوهر واحد ثلاثة أقانيم؛ أقنوم الأب، وأقنوم الابن، وأقنوم روح القدس؟ قلت: أما المعاني فلا طريق إلى إثباتا، وما لا طريق إلى إثباته وجب نفيه، كما وجب نفي معاني زائدة عليها لانتفاء الطريق إلى

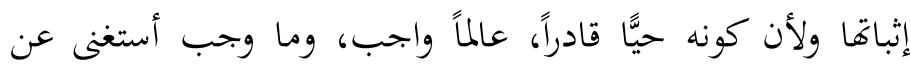
موجب 30.

ونفى الإمام الزّخشريّ قول البموس، وقول النصارى، وقول الثنوية، فقول المجوس بقدم الشيطان باطل لأن الجسم لا يكون قديماً، ومن جعله غير جسم مثلاً للقديم فهو أبطل لأنه لا يصح إثبات قديمين مثلين، أما النصارى فإن جعلوا الأقانيم أشخاصاً فهي محدثة، وإن أردوا بأقنوم الأب: الذات، وبأقنوم الابن: العلم، وبأقنوم روح القدس: الحياة، فالرد عليهم عند الزّخشريّ نفس الرد على الأشعرية.

${ }^{30}$ Ibid., 18-19. 
Syed Mohammad Hilmi \& Mohd Khairul Naim, "Transcendence of Allah According to al-Zamakhshari \& al-Nasafï," Afkār Vol. 19 Issue 1 (2017): $163-222$

وعن قول الثنوية بالنور والظلمة فذلك أيضا باطل حيث يقول الإمام: "فإن كانا جسمين أو عرضين فهما محدثان، ويلزم إن كانا عرضين قديمين أن يكون محلاهما قديمين مثلهما، وهو خروج من التثنية إلى التربيع 131".

والإمام الزّمخشريّ يثبت قدم الله - تعالى - كما ذهب

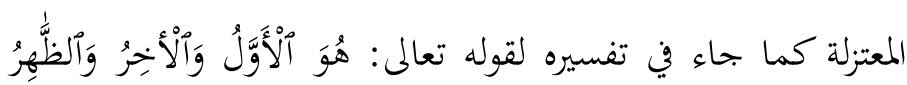

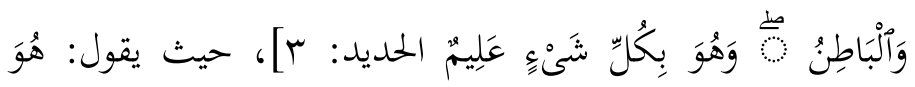

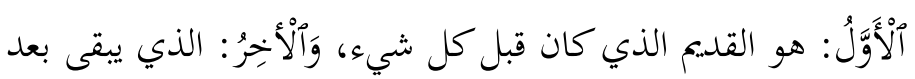

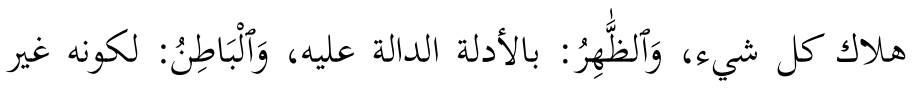
مدرك بالحواس 32.

فالله - سبحانه وتعالى - عند الزّخشريّ لو لم يكن قديما كان حادثا، إذ لا واسطة بين القديم والحادث لانحصار الموجودات فيهما. ولو كان حادث لافتقر إلى محدث، ولو افتقر إلى محدث لافتقر محدثه إلى محدث آخر لانعقاد المماثلة بينهما فيلزم التسلسل أو الدور وهما محالان باطلان، وإذا بطلا بطل حدوث الإله، واذا بطل الحدوث وجب القدم وهذا ما ذهب إليه المتكلمون ومنهم الإمام الزّخشريّ.

${ }^{31}$ Ibid., 20.

${ }^{32}$ Al-Zamakhshari, al-Kashshāf, 4:470. 
Syed Mohammad Hilmi \& Mohd Khairul Naim, "Transcendence of Allah According to al-Zamakhshari \& al-Nasafï," Afkār Vol. 19 Issue 1 (2017):

فالزّخشريّ ذهب إلى أن القدم هو أخص صفات الله - تعالى

- و يدلل على ذلك بأن الصّّفات الوجودية لو قامت بذات الله تعالى - لكان الله - تعالى - مفتقراً إليها، وبهذا يكون الله مفتقراً إلى غيره، ولأها أعراض لا تقوم إلا بجسم، والجسم مركب، والمركب مككن محتاج، وذلك عين النقص، ثم إن إثبات الصّفات لله يؤدي إلى ولى مشاركته في القدم الذي هو أخص صفاته. غير أن تعيين (القدم) كأخص صفات الباري - تعالى - ليس

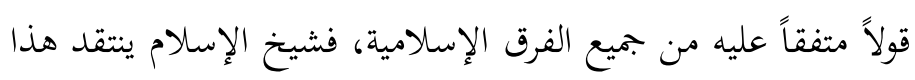

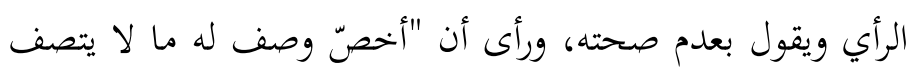
به غيره: مثل كونه رب العالمين، وأنه على كل شيء قدير، وأنه بكل شيء عليم. والقدم ليس من خصائص الذات المحردة، بل من خصائص الذات الموصوفة بصفات، وإلا فالذات البمرّدة لا وجود لها فضلاً عن أن تختص بالقدم. فالذات متصفة بالقدم، والصفات متصفة بالقدم، وليست الصّفات إلهاً ولا رباً، كما أن النبي محدث باث بات وصفاته محدثة، وليست صفاته نبيا 33

33 Taqi al-Dīn Abū al-`Abbās Aḥmad bin 'Abd al-Halīm bin Taymiyyah al-Harrānī, Majmū al-Fatāwā, ed. `Abd al-Rahmman bin Muḥammad (Al-Madīnah: Mujamma`al-Malik Fahd li al-Ṭibā`ah alMuṣhaf al-Sharif, 1995), 3:70. 
Syed Mohammad Hilmi \& Mohd Khairul Naim, "Transcendence of Allah According to al-Zamakhshari \& al-Nasafï," Afkār Vol. 19 Issue 1 (2017):

وعن معرفة القديم بصفاته وعن خخالفته - تعالى - للحوادث،

يقول الإمام الزّخشريّ: "اعلم أن محدث العالم شيء مخالف لسائر

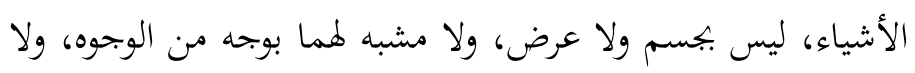
يشغل جهة ولا يحل في جرم ولا يكون في مكان، ولا يدرك بحاسة من الحواس، وليس بمرئي في نفسه، قديم مختص بالأولية، لم يتقدم عدم،

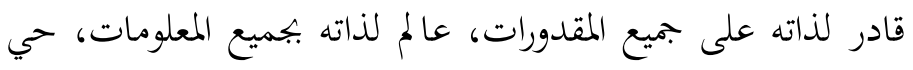

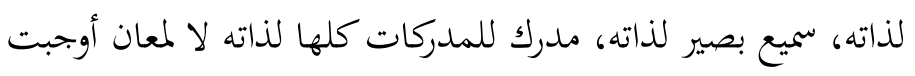
ذلك، متكلم بكلام يخلقه في بعض الأجرام، كما يخلق سائر الأعراض، مريد غني، لا يجوز عليه الحاجات، واحد فرد لا ثاني له،

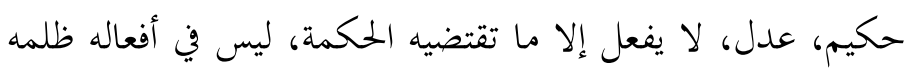
ولا عبث، فنزه عن جميع المقبحات، متعال عن أن يضل عباده، ثم يعذبهم أو يعاقب على غير جرم، أو يكلف ما لا يطاق، ومن

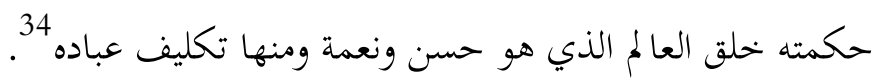
الأجسام والأعراض عند الإمام الزّخشريّ محدثة، والقديم هو الله - تعالى - وحده، وهو محدِث كل محََث، منزه عن مشابهة المخلوقات من كل نواح، مخالفها في لوازمها تمتم المخالفة، وصفاته ليست معان قديمة قائمة بذاته، بل كل كمالاته للذاته. ولا يخلق

${ }^{34}$ Al-Zamakhshari, Kitāb al-Minhāj, 20. 
Syed Mohammad Hilmi \& Mohd Khairul Naim, "Transcendence of Allah According to al-Zamakhshari \& al-Nasafï," Afkār Vol. 19 Issue 1 (2017):

أفعال عباده، لأن في نسبة خلقها له نسبة الظلم له - تعالى -، فأفعال العباد فيها من القبائح التي تنزه الله عنها. فمن ضل من العباد فإنما يضل لأنه اختار الضلال لنفسه وخلقه، ليس الله - تعالى خحلقه.

وقد أورد الإمام الزّخشريّ أسئلة افتراضية في كتابه المنهاج كما هو فجه في عرض معتقداته وتقريرها - وأجاب عنها وهو يدلل على قدم الله - تعالى -، وحدوث الحوادث، منها: 1. فإن قلت لم كان القديم واجب الوجود في كل حال؟ قلت: لأن القديم ما لا أول لوجوده، فلو كان وجوده جائزاً كوجود غيره لاحتاج إلى موجد، وذلك ينافي القدم، فوجب وجوده

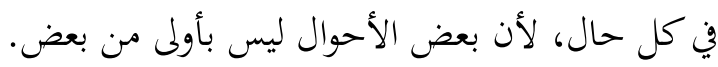

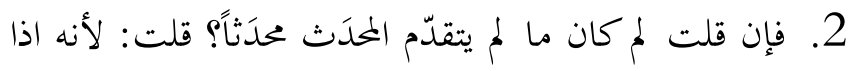
لم يتقدمه كان معدوما قبله ثم وجد وهي حقيقة الحلدوث. 3. فإن قلت: ما لدليل على حدوث الأعراض؟ قلت: جواز العدم عليها، وفيها ما لا بقاء له كالصوت ولا توجد إلا في الأجسام، والأجسام قد ثبت حدوثها فكانت محدثة مثلها. 
Syed Mohammad Hilmi \& Mohd Khairul Naim, "Transcendence of Allah According to al-Zamakhshari \& al-Nasafï," Afkār Vol. 19 Issue 1 (2017): $163-222$

4. فإن قلت: ما الدليل على أن الله - تعالى - قديع؟ قلت لأن القول بالحدوث يؤدّي إلى تسلسل الحوادث وهو محال، وما أدى إلى المحال فهو محال فصحّ أنه قديم. 5. فإن قلت: لمجكان التسلسل محالا قلت: لأن كل حادث قد سبقه عدم إلى غير فاية، فلو تسلسلت الحوادث إلى غير هاية، لسابق وجودها عدمها، واستوى السابق والمسبوق، ولأنه لا دليل على الحدوث، وما لا دليل عليه وجب نفيه، واذا انتفى الحدوث ثبت القدم. 6. فإن قلت ما الدليل على أنه شيء خخالف للأشياء؟ قلت: الأشياء هي الأجرام والأعراض، فاذا صحّ أنه ليس منها صحّ أنه مخالف للأشياء مغاير لها 35.

فالإمام الزّخشريّ يقول بقول القاضي عبد الجبار والمعتزلة مع أن المتكلمين اختلفوا في معنى القول في الله أنه قديم، فقال بعضهم: معنى القول عن الله قديم أنه لم يزل كائنا لا إلى أول وأنه المتقدم لجميع المحدثات لا إلى غاية، وقال عباد بن سليمان: معنى قولنا في الله أنه قديم أنه لم يزل - ومعنى لم يزل - هو أنه قديم، وأنكر عباد

${ }^{35}$ Al-Zamakhshari, Kitāb al-Minhāj, 11-12. 
Syed Mohammad Hilmi \& Mohd Khairul Naim, "Transcendence of Allah

According to al-Zamakhshari \& al-Nasafï," Afkār Vol. 19 Issue 1 (2017):

القول بأن الله كائن متقدم للمحدثات، وقال: لا يجوز أن يقال ذلك،

$$
\text { وقد قال البعض البغداديين: معنى قديم أنه إله } 36 .
$$

ومن الآية التي تكلم فيها الإمام الزّخشريّ وذكرها دليلاً على

خخالفته - تعالى - للحوادث ونفي المشابهة عن ذاته هي قوله - تعالى

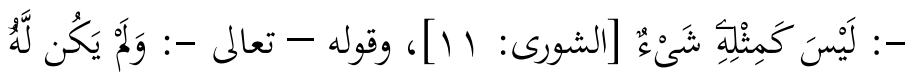

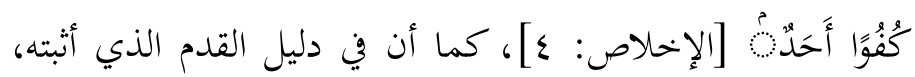
وفي أنه - تعالى - لو لم يكن مخالفاً للحوادث لكان مماثلاً لما، ولو كان ذلك لكان حادثاً، دليلاً على تنزيه الله - تعالى - عند الإمام الزّخشريّ، وإثباتاً ودليلاً على قدم الله - تعالى -. وهذا ما تستلزمه الألوهية، وما يليق بكمال الله - تعالى - .

كما أن الزّخشريّ قرّر أن لو أمكن أن يلحق الله العدم لاستحال عليه القدم، وهذا محال في حق الله - تعالى -، فالقاعدة التي اعتمد عليها تقول: كل ما ثبت له القدم استحال عليه العدم. فالله - تعالى - غير محتاج إلى محلّ ولا إلى ذات يقوم بها، أو موجد يوجده، فهو الغني الذي لا يحتاج إلى غيره، فالله لا يفتقر إلى مخصّص أي: ذات يقوم بها، لأنه لو افتقر إلى ذلك لكان حادثاً، وكيف ذلك وقد سبق وجوب وجوده، وقدمه، وبقائه، ذاتاً وصفاتاً.

${ }^{36}$ Abū al-Ḥasan al-Ash `arī 'Alì bin Ismā'ìl, Maqālāt al-Islāmiyyīn wa Ikhtilāf al-Muṣallīn (Beirut: Dār Ihyā’ al-Turāth al-'Arabī, n.d), 180. 
Syed Mohammad Hilmi \& Mohd Khairul Naim, "Transcendence of Allah

According to al-Zamakhshari \& al-Nasafï," Afkār Vol. 19 Issue 1 (2017):

163-222

تنزيه الله - تعالى - عند الإمام النّسفيّ مع المقارنة بينه وبين

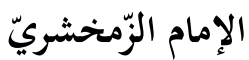

لقد أثبت الإمام النّسفيّ الصّفات لله، كما أثبتها - سبحانه لنفسه، وهو متفق مع أهل السيّة في نفي الكيف والتشبيه، فلا مثل

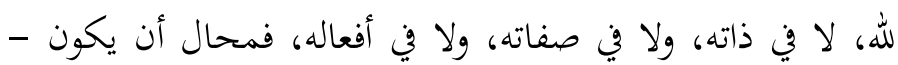

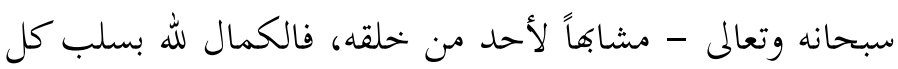
نقص لا يليق بذاته.

وقد جاء كلامه موافقاً شيوخ الماتريديّة في نفيهم مماثلة الله - لإل تعالى - لأحد بين مخلوقاته، فالله - سبحانه - لا يشبه المخلوقات

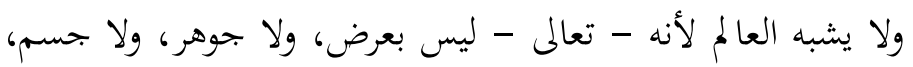
فالقول بالتشبيه باطل عنده، فالصفات هي الصّفات التي وصف الله - تعالى - بها نفسه والتي تنزهت أن تشابه صفات المخلوقين، والتي أثبتت له - تعالى - الكمال المطلق فنفت عنه المكانيّة، والعرضيّة، والجسميّة، ومماثلته - تعالى - للحوادث. وأثبتت له القدم، والقيام بنفسه، والوحدانية، فلا هو - تعالى - يشبه الأجرام ولا الأجسام، ولا الحادثات والمتحيزات، ولا كل من خلق، ولا يوصف بالتغير، والتبدل، ولا بالنماء، والتطور، ولا يحل بمكان، فكان ولا زمان ولا مكان، وهو الآن على ما عليه كان، ولا 
Syed Mohammad Hilmi \& Mohd Khairul Naim, "Transcendence of Allah

According to al-Zamakhshari \& al-Nasafï," Afkār Vol. 19 Issue 1 (2017):

$163-222$

شبيه له ولا مثيل، فلا ذاته كالذوات، ولا صفاته تشبه الصفات، فلا وجه له كالصور المصورة، فرؤيته بلا كيف، فهو على العرش كيف شاء، وكما شاء، ولا تعطيل لصفات، ولا اعتقاد بتجسيم وتكييف، فمن قال بالتجسيم والتشبيه لم يقدر الله حق قدره، ولم ينزهه بسلب

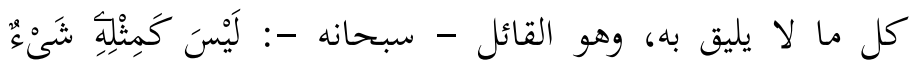
[الشورى: 11]]، وله المثل الأعلى، فلا تضرب له الأمثال.

يقول الإمام النّسفيّ رحمه الله - في تفسير قوله - تعالى -:

لَيْسَ كَمِنْلِِِ شَىْهُ: "قيل: إن كلمة التشبيه كرّرت لتأكيد نفي التماثل، وتقديره ليس كمثله شيء، وقيل: المثل زيادة وتقديره: ليس ك(هو)

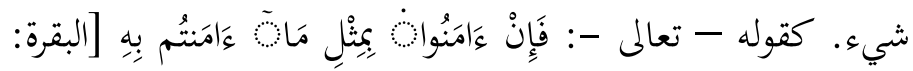

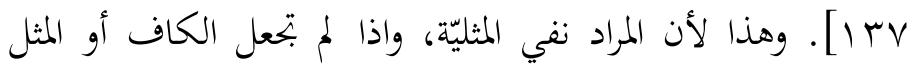
زيادة كان إثبات المثل 37 .

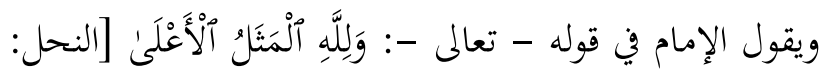

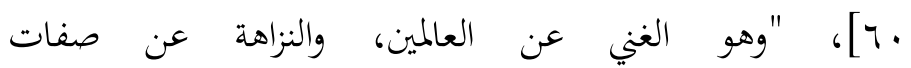

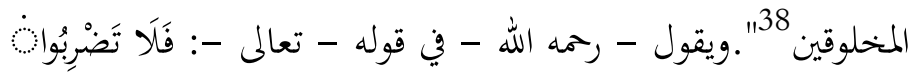

${ }^{37}$ Abū al-Barakāt `Abd Allāh bin Aḥmad bin Maḥmūd Hāfiz al-Dīn alNasafī, Tafsìr al-Nasafī Madārik al-Tanzīl wa Haqā'iq al-Ta'wìl, ed. Yūsuf 'Alī and Muhy al-Dīn Dīb Mistū (Beirut: Dār al-Kalam alTayyib, 1998), 3:247.

${ }^{38}$ Ibid., 2:218. 
Syed Mohammad Hilmi \& Mohd Khairul Naim, "Transcendence of Allah According to al-Zamakhshari \& al-Nasafï," Afkār Vol. 19 Issue 1 (2017): $163-222$

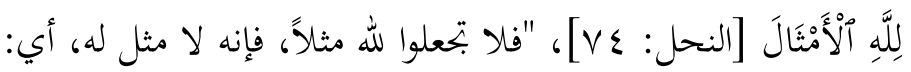
لا تجعلوا له شركاء" يقتضي نقصاً وتشبهاً بالخلق 39"، كما يقول في لِّل



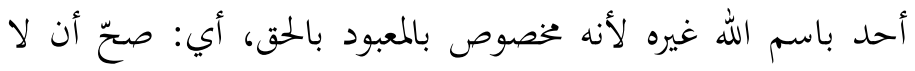
معبود يوجه إليه العبادة إلا هو وحده، لم يكن بدّ من عبادته، والاصطبار على مشاقها 40". نزه الإمام النّسفيّ الله - تعالى - عندما تكلم عن الوحدانية؛ فعبادة الله، وتوحيده، والإيمان به، تكون باجتناب الطاغوت. فطاعته - تعالى - لا تكون إلا بالكفر بالطاغوت، والإيمان به وحده، وهذا ما دعا إليه جميع الرسل من نوح إلى محمد عليهم السلام وهي شهادة أن لا إله إلا الله حيث يقول - سبحانه وتعالى -: وَمَاَّ أَرْمَلْنَا مِن

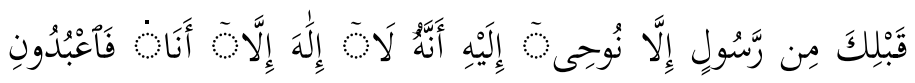

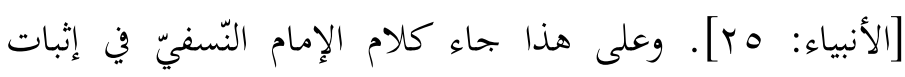

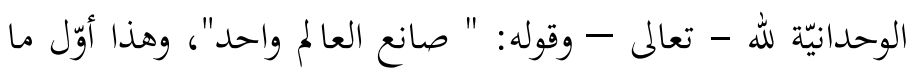
تكلم به عن الوحدانيّة وأغها عقيدة الرسل السماوية بأكملها حيث

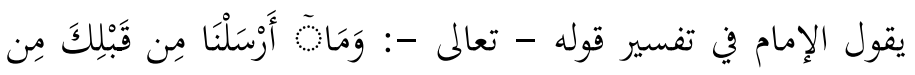

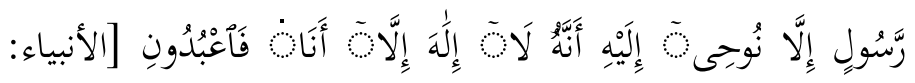

${ }^{39}$ Ibid., 2:224.
${ }^{40}$ Ibid., 2:345. 
Syed Mohammad Hilmi \& Mohd Khairul Naim, "Transcendence of Allah According to al-Zamakhshari \& al-Nasafï," Afkār Vol. 19 Issue 1 (2017):

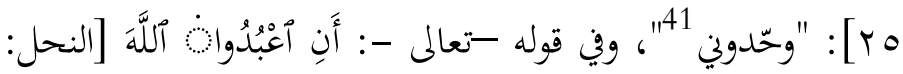

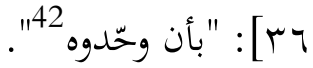

وقد أثبت الإمام النّسفيّ وحدانيّة الله معتمداً على ما اعتمد عليه المعتزلة والماتريديّة في قوهم بدليل التمانع دليالً على وحدانيّة الله - تعالى -، حيث يقول الإمام النّسفيّ: "إذ لو كان له صانعان، لثبت بينهما تمانع، وذا دليل حدوثهما، أو حدوث أحدهما، فإن أحدهما لو أراد أن يخلق في شخص حياة، والآخر موتاً، فإما أن يكصل مرادها وهو محال، أو تعطلت إرادةما وهو تعجيزها، أو نفذت إرادة أحدهما دون الآخر، وفيه تعجيز من لم تنفذ إرادته، والعاجز فيحط عن درجة الألوهية، اذ العجز من أمارات الحدوث، وإذا لم يتصور صانعيه كان واحداً ضرورة 13 ".

فبرهان التمانع هذا تكلم به المتكلمون قبل الإمام النّسفيّ، ولكن لما كان الإمام النّسفيّ ماتريدي العقيدة فهو يقول قول الماتريديّة في إثبات الصانع ووحدانيته وينهج فج شيوخهم فالإمام أبو معين النّسفيّ في إثبات الصانع ووحدانيته يقول: "وإذا ثبت للعالم محدثا

\footnotetext{
${ }^{41}$ Ibid., 2:400.

${ }^{42}$ Ibid., 2:212.

${ }^{43}$ Ibrāhìm `Abd al-Shāfīi Ibrāhịim, "Kitāb `Umdah al-`Aqā’'id li al-Imām Abī al-Barakāt al-Nasafīi Dirāsah wa Tahqị"” (Master Dissertation, Faculty of Ușūl al-Dīn, University of al-Azhar, 1987), 171.
} 
Syed Mohammad Hilmi \& Mohd Khairul Naim, "Transcendence of Allah According to al-Zamakhshari \& al-Nasafï," Afkār Vol. 19 Issue 1 (2017):

أحدثه، وصانعا صنعه كان الصانع واحداً، اذ لو كان له صانعان لثبت بينهما تمانع، وذلك دليل حدوثهما أو حدوث أحدهما. فإن أحدها لو أراد أن يخلق في شخص حياة، والآخر أراد أن يخلق فيه موتاً، وكذا هذا في جميع المتضادين، كالحركة والسكون، والاجتماع والافتراق، والسواد والبياض وغير ذلك، إما إن حصل مرادهما ووجد في المحل المتضادان، وهو محال شخص واحد في حالة واحدة، وإما إن تعطلت ارادتمما، ولم ينفذ ولم يحصل لا هذا ولا ذاك، وهو تعجيزهما. وإما إن نفذت إرادة أحدهما دون الآخر وفيه تعجيز من لم تنفذ إرادته والعجز من أمارات الحدث. فإذا لم يتصور إثبات صانعين قديمين للعالم فكان الصانع واحداً ضرورة 44 وأحسب أن كلام الإمامين راجع إلى قول أبي منصور الماتريدي عندما ساق دليل العقل على وحدانيته - تعالى - حيث ذهب الإمام إلى أن لو كان إلهين لاختلفا في الإرادة، ويحاول كل واحد منها منع

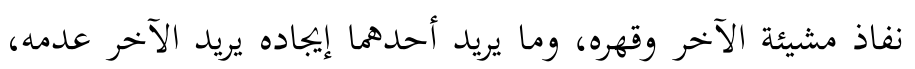

${ }^{44}$ Abū al-Ma`in Maymūn al-Nasafî, al-Tamhìd li Qawā'id al-Tawhìd, ed. Aḥmad Farid, 1st edition (Beirut: Dar al-Kutub al-'Ilmiyyah, 2007), 17. 
Syed Mohammad Hilmi \& Mohd Khairul Naim, "Transcendence of Allah

According to al-Zamakhshari \& al-Nasafï," Afkār Vol. 19 Issue 1 (2017):

$163-222$

وكذلك الحال الإبقاء والإفناء، وفي ذلك تناقض، وتنافٍ، فدلّ

$$
\text { الوجود على محدث العالم واحد }{ }^{45}
$$

وفي تفسير الإمام رحمه الله - لآية: قُُْ هُوَ أللَّهُ أَحَدُ

[الإخلاص:1]]، يثبت الإمام النّسفيّ الدليل على الوحدانية، حيث

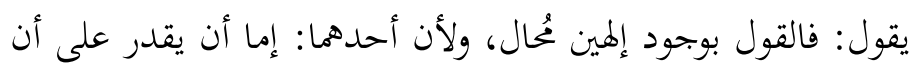

يستر شيئاً من أفعاله عن الآخر أولا يقدر، فإن قدر لزم كون المستور


على وحدانية الله - تعالى - بصفة الكمال، فإن كانا إلهين، فالجماهل من أحدهما لا يكون إلها، كما أن العاجز ليس بإله. ثم إن كان من يدبر العالم إلهين اثنين، أفلا يعجز أن يكون في تدبيره إله واحد، فيتنفي أحد الإلهين لاكتفاء أثر إلى مؤثر واحد،

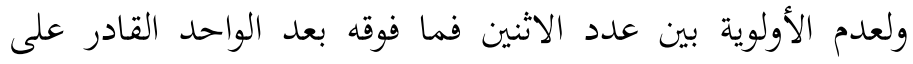
الخلق والتدبير؟ وفي هذا قال الإمام النّسفيّ: "والدليل على أنه واحد من جهة العقل، أن الواحد؛ إما أن يكون في تدبير العالم وتخليقه كافياً أو لا، فإن كان كافياً كان الآخر ضائعاً غير محتاج إليه، وذلك نقص، والناقص لا يكون إلهاً، وإن لم يكن كافياً فهو ناقص، ولأن

${ }^{45}$ Al-Māturìī, al-Tawhìd, ed. Fath Allāh Khalīf (Alexandria: Dār alJāmi āt al-Mișriyyah, n.d), 20.

${ }^{46}$ Al-Nasafî, Tafsìr al- Nasafï, 3:694. 
Syed Mohammad Hilmi \& Mohd Khairul Naim, "Transcendence of Allah According to al-Zamakhshari \& al-Nasafï," Afkār Vol. 19 Issue 1 (2017):

العقل يقتضي احتياج المفعول إلى فاعل، والفاعل الواحد كافِ، وما وراء الواحد فليس عدد أولي من عدد فيقضى ذلك إلى وجود أعداد لا غهاية لها، وذا محال "47".

ففي تفسير الإمام النّسفيّ هذا ما جاء موافقاً لكلام أبي

منصور وإن اختلف الكلام فالمعنى واحد، حيث يقول الماتريدي: إنه "لو كان أكثر من واحد لتقلب فيهم التدبير، نحو: أن تحول الأزمنة من الشتاء والصيف، أو تحول خروج الإنزال ومنعها، أو تقدير السماء والأرض، أو تسيير الشمس والقمر والنجوم، أو أغذية الخلق،


من التدبير، وإنساق ذلك على سنن واحد لا يتم بمدبرين لذلك لزم

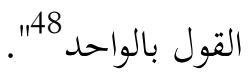

كما يقول الإمام النّسفيّ في قوله - - تعالى -


بالوحدانيّة، ونفي الشريك، وبأنه المتفرّد بإيجاد المعدومات، والمتوحّد



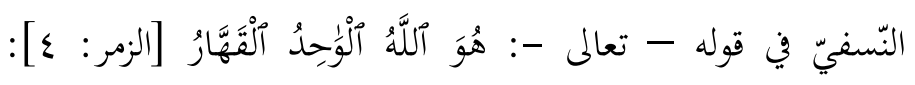

${ }^{47}$ Ibid.

${ }^{48}$ Al-Māturìì, al-Tawhìid, 21.

${ }^{49}$ Al-Nasafí, Tafsìr al-Nasafï, 3:695. 
Syed Mohammad Hilmi \& Mohd Khairul Naim, "Transcendence of Allah According to al-Zamakhshari \& al-Nasafï," Afkār Vol. 19 Issue 1 (2017):

"يعني: أنه واحد متبرئ عن انضمام الأعداد، متعال عن التجزؤ، والولاد، قهار غلاب لكل شيء، ومن الأشياء آلتهم، فأنى يكون له أولياء وشركاء 50.



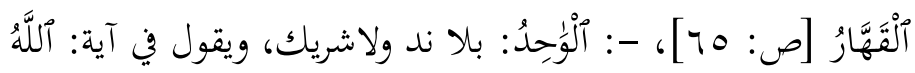

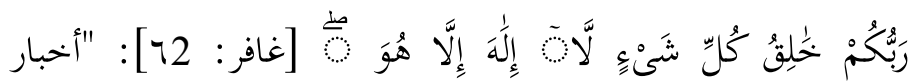
مترادفة أي هو الجامع لمذه الأوصاف من الربوبية والإلهية وخلق كل

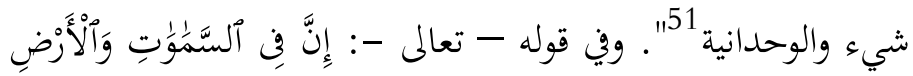

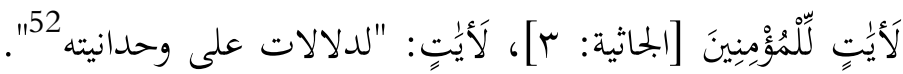
وهذا ما ذهب إليه الماتريدي عندما استدل بالحلق دليل على برهان

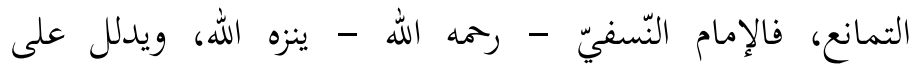

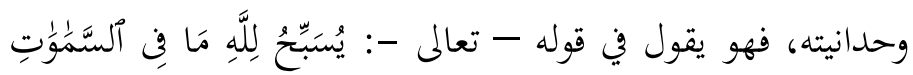
وَمَا فِ ألْأَْْضِ [المِمعة: 1]]: "إما أن يكون تسبيح خلقة يعني إذا نظرت إلى كل شيء دلتك خلقته على وحدانية الله - تعالى وتنزيهه عن الأشباه، أو تسبيح معرفة بأن يجعل الله بلطفه في كل شيء ما يعرف به الله - تعالى -وينزهه 53.".

${ }^{50}$ Ibid., 3:169.

${ }^{51}$ Ibid., 3:219.

${ }^{52}$ Ibid., 3:297.

${ }^{53}$ Ibid., 3:479. 
Syed Mohammad Hilmi \& Mohd Khairul Naim, "Transcendence of Allah According to al-Zamakhshari \& al-Nasafï," Afkār Vol. 19 Issue 1 (2017): $163-222$

وكما ذهب المتكلمون إلى وحدانية الله بدليل التمانع في قوله - تعالى

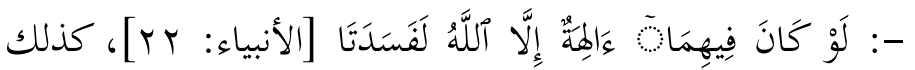
ذهب الإمام النّسفيّ في تفسير الآية حيث يقول: "والمعنى: لو كان يدبر أمر السموات والأرض آلهة شتى غير الواحد الذي هو فاطرهما


على أن وجود أكثر من إله يجعلهم يتنازعون فيما بينهم، ويحاول كل واحد منهم أن يكون له السلطان وقهر غيره، ولو كان الإله أكثر من واحد لفسد العالم، ولكن بدليل المشاهدة العالم ليس بفاسد، وهذا

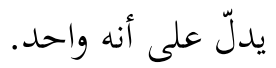

\section{وفي القول بقدم الله وفي نفي الإمام لمماثلة الله للحدوث}

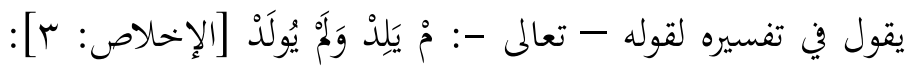

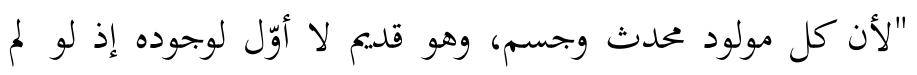
يكن قديماً لكان حادثاً لعدم الواسطة بينهما، ولو كان حادثاً لافتقر إلى محدث، وكذا الثاني، والثالث، فيؤدي إلى التسلسل، وهو باطل. وليس بجسم لأنه اسم للمتركب، ولا يخلو حينئذ من أن يتصف كل جزء منه بصفات الكمال فيكون كل جزء إلهاً فيفسد القول به، كما

${ }^{54}$ Ibid., 2:399. 
Syed Mohammad Hilmi \& Mohd Khairul Naim, "Transcendence of Allah According to al-Zamakhshari \& al-Nasafï," Afkār Vol. 19 Issue 1 (2017):

فسد بإلهين، أو غير متصف بها بل بأضدادها من سمات الحدوث،




[الإخلاص: ؟]]: " نفيُ أن يماثله شيء، ومن زعم أن نفي الكفء - وهو المثل - في الماضي لا يدلّ على نفيه للحال، والكفار يدّعونه في الحال، فقد تاه في غيّه لأنه إذا لم يكن فيما مضى لم يكن في الحال ضرورة، إذ الحادث لا يكون كفؤاً للقديم، وحاصل كلام الكفرة يؤول إلى الإشراك والتشبيه والتعطيل 56".

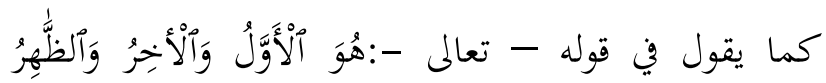
وَالْبَبَاطِنُ [الحديد: ب]، هُوَ أْلْوََّلُ: هو القديم الذي كان قبل كل


الدالة عليه، 'ألبَاطِنُ: لكونه غير مدرك بالحواس، وإن كان مرئيا 57". وقد عرف الإمام النّسفيّ القديم بأنه: ما لا ابتداء لوجوده، والحادث: ما لوجوده ابتداء، وبيّن الإمام أنه لو كان الإله حادثا لاحتاج إلى محدثه، ومحدثه احتاج إلى محدث آخر وهكذا إلى ما لا هاية، وهذا هو التسلسل، والتسلسل باطل، لأن المحدثات احتاجت

${ }_{55}^{55}$ Ibid., 3:395-395.

${ }^{56}$ Ibid., 3:395.

${ }^{57}$ Ibid., 3:433. 
Syed Mohammad Hilmi \& Mohd Khairul Naim, "Transcendence of Allah According to al-Zamakhshari \& al-Nasafï," Afkār Vol. 19 Issue 1 (2017): $163-222$

إلى علة، لكوها لا يجوز أن تُحدث نفسها، ولا بعضها لاستحالة أن يكون الشيء علة لنفسه أو لبعضه، بل خارجاً عنها، فيكون واجباً، وعندئذ ينقطع التسلسل.

وبعبارة أخرى بيّن الإمام أن المفتقر إلى الممكن أولى بالإمكان، فيكون له مؤثر، وذاك المؤثر إما أن يكون نفسه وهو محال، لأن شأن المؤثر أن يكون متقدماً بالرتبة على الأثر، وتقدم الشيء على نفسه محال. والنتيجة أنه من المعلوم أن الخارج عن كل الممكنات لا يكون

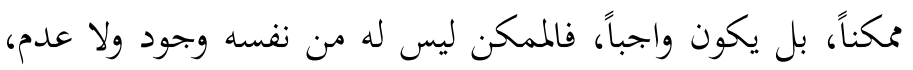
فإذا كان الأمر كذلك: فإن جميع الممكنات تنتهي إلى موجود واجب الوجود لذاته، وهو القديم، وبهذا الكلام أثبت الإمام صفة القديم لله

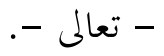
كما يقول الإمام في قوله - تعالى -: إِنَّ فِ خَلْقِ آلسَّمَُّوتِ

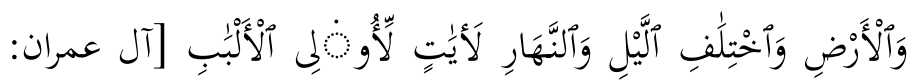

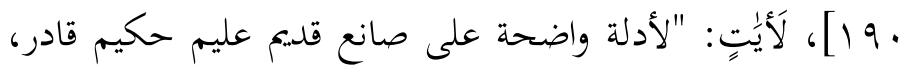

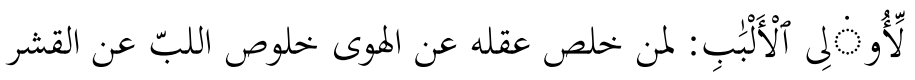
فيرى أن العرض المحدث في الجواهر يدلّ على حدوث الجواهر، لأن جوهراً ما لا ينفك عن عرضٍ حادثُ، وما لا يخلو عن الحادث فهو

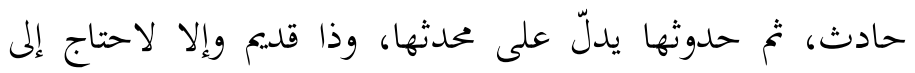


Syed Mohammad Hilmi \& Mohd Khairul Naim, "Transcendence of Allah According to al-Zamakhshari \& al-Nasafï," Afkār Vol. 19 Issue 1 (2017): $163-222$

محدث آخر إلى مالا يتناهى وحسن صنعه يدلّ على علمه وإتقانه يدلّ على حكمته وبقاؤه يدلّ على قدرته 58.". وفي قوله وتفسيره هذا يذهب الإمام مذهب المتكلمين في فساد القول بتعدد الآلمة لإثبات صفة القدم الله - تعالى - كما ذهب إلى ذلك أبو منصور الماتريدي، ويذهب الإمام في تفسيره إلى نفي الولد وإضافته إلى الله - سبحانه - فنزها الله عن ذلك، ففي تفسيره

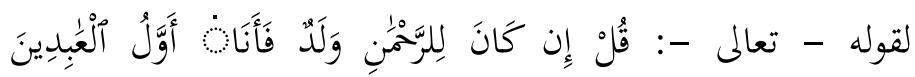

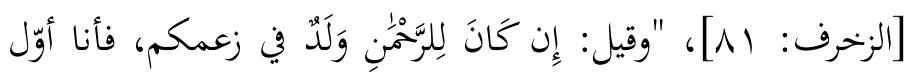
العابدين، أي: الموحّدين لله المكذبين قولكم بإضافة الولد إليه، وقيل:



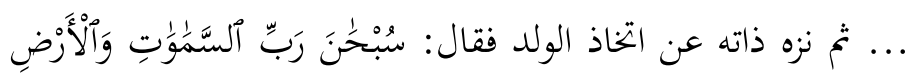

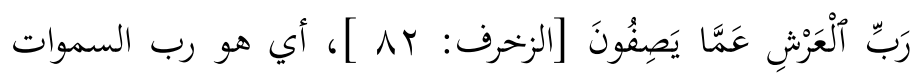

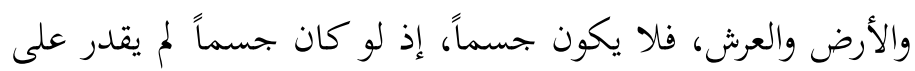
خلقها، وإذا لم يكن جسماً لا يكون له ولد، لأن التولد من صفة

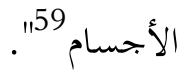

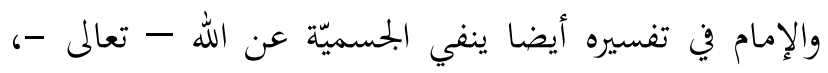

ولذلك أراه يقول عند كلامه عن الرؤية في تفسيره لقوله - تعالى -:

${ }^{58}$ Ibid., 1:320.

${ }^{59}$ Ibid., 3:283. 
Syed Mohammad Hilmi \& Mohd Khairul Naim, "Transcendence of Allah

According to al-Zamakhshari \& al-Nasafï," Afkār Vol. 19 Issue 1 (2017):

أَوْ مِن وَرَاَئِ حِجَابٍ [الشورى: 101]: "وليس المراد به حجاب الله

- تعالى -، لأن الله تعالى لا يجيوز عليه ما يجوز على الأجسام من

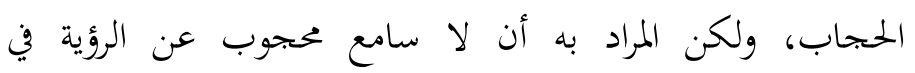

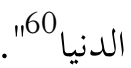

كما نزه لله - سبحانه - أن يكون له ولد عند تفسيره لقوله - تعالى

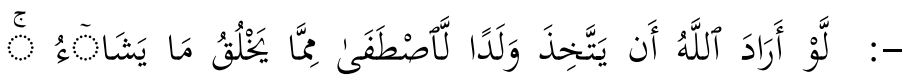

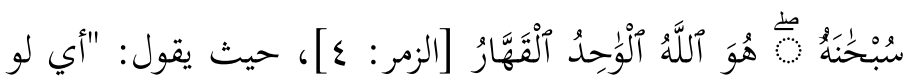

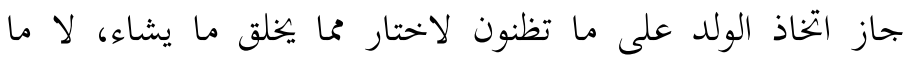
تختارون أنتم وتشاؤون، سُبْحَنَهُ: نزه ذاته عن أن يكون له أخذَ ما لها نسبوا إليه من الأولياء والأولاد".

وعلى ما سبق بيانه أجد أن الإمام النّسفيّ ينزه الله - تعالى عن الحوادث ولوازمها، مبيّناً أن صانع العالم ليس بعرض، لأنه يقول بأن العرض يستحيل بقاؤه، ولأنه إن كان باقياً فإما أن يكون بقاؤه


إطلاق لفظ الجوهر والجسم والعلة على الله - تعالى - يعتبر إلحاداً. ثم يبين أن الجوهر متحيز، وبناءً عليه فهو لا يخلو عن الحركة والسكون، وما كان كذلك فهو حادث. ثم ينفي عن الله الجسمية

${ }^{60}$ Ibid., 3:262. 
Syed Mohammad Hilmi \& Mohd Khairul Naim, "Transcendence of Allah According to al-Zamakhshari \& al-Nasafï," Afkār Vol. 19 Issue 1 (2017):

لأن الجسم اسم مركّب وأن من أطلق لفظ الجسم وعنى به المتركب فهو يخطئ في الاسم والمعنى. ثم يبين الإمام أن من أطلق الجسمب وعنى تركي به القائم بالذات لا المتركب فهو مخطئ أيضاً، لأن مصدر إطلاق

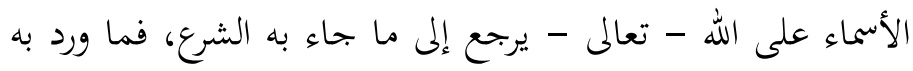

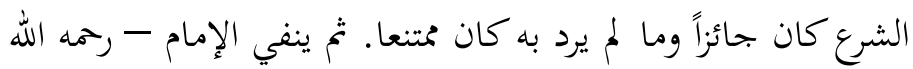

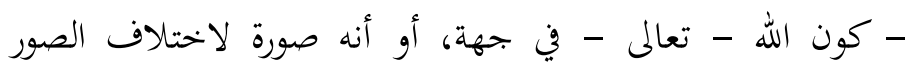
والجهات، كما لا يجوز وصفه - تعالى - باللون أو الطعم الرائحة، أو وصفه بالتبّضض، والتناهي، ومشاهمة المحدثات. ويبطل قول من قال من المشبّهة والكرامية بأن الله متمكن على العرث لأن التعري عن المكان ثابت في الأزل، لعدم قدم المكان، فلو تمكن بعد خلق المكان لتغيّر ولحدثت فيه مماسة، والتغير، وقبول

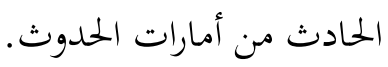
وعندما يذكر معنى الاستواء يفسّره بمعنى الاستيلاء، مع أنه في تفسيره للاستواء بمعنى الاستيلاء يوافق رأي القاضي عبد الجبار، لأن

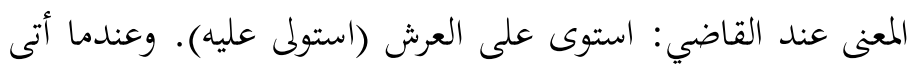
إلى الحديث عن الصّفات الخبرية والألفاظ الموهمة للتشبيه سأبيّن رأي الإمام النّسفيّ وتفسيره لها. 
Syed Mohammad Hilmi \& Mohd Khairul Naim, "Transcendence of Allah

According to al-Zamakhshari \& al-Nasafï," Afkār Vol. 19 Issue 1 (2017):

$163-222$

وقال محقق كتاب عمدة العقائد،: "ونرى المصنف (يعني الإمام

النّسفيّ) رحه الله يفسّر كل آيات الاستيلاء على العرش في القرآن بالاستيلاء، ولكي ينتصر لرأيه هذا يتكلف تطويع النصوص القرآنية، اذ يبيّن أن الله - تعالى - تمدّح بالاستواء الذي يفهم منه الاستيلاء، ويستدل المصنف (الإمام) بقول الشاعر:

61

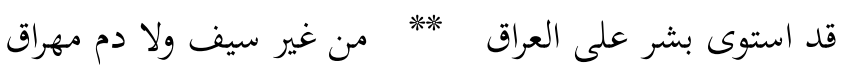
... إلى أن يقول: وأرى المصنف (الإمام النّسفيّ) قد سلك نفس المسلك الاعتزالي في تأويله الاستواء بمعنى الاستيلاء 62 فرأيي في هذا الكالام أن الإمام النّسفيّ أتى بأكثر من معنى لتفسير لفظة الاستواء

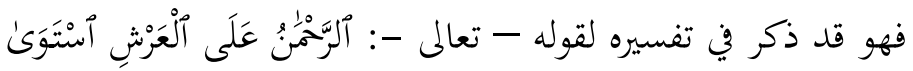

تعجبّت عندما وجدت أن قائل هذا البيت هو الأخطل النصرائّ، كيف يستدلّ على 61

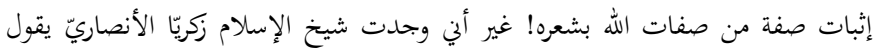

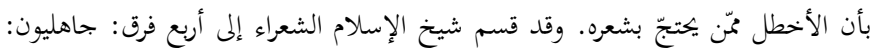

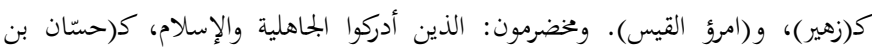
ثابت، و(لبيد). وإسلاميون: الذين وجدوا في صدر الإسلام، كر(فرزدق)، و(الأخطل).

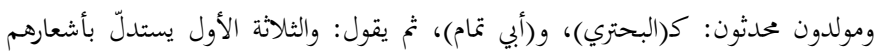

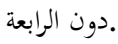

See: Zakariyyā al-Anșāīi, Hāshiyah Zakariyyā al-Anșārī alMusammāh Fath al-Ilāh al-Majìd bi Ị̇āh Sharh al-'Aqā'id 'alā Sharh al-'Aqā'id al-Nasafiyyah li Sa'd al-Dīn al-Taftāzānī, ed. 'Urfah `Abd al-Raḥmān al-Nādì (Kuwait: Dār al-Diyā', 2013), 351352.

${ }^{62}$ Ibrāhīm, Kitāb 'Umdah al- 'Aqā’ 'id, 57-58. 
Syed Mohammad Hilmi \& Mohd Khairul Naim, "Transcendence of Allah According to al-Zamakhshari \& al-Nasafï," Afkār Vol. 19 Issue 1 (2017):

[طه: 0]، أن استوى بمعنى: استولى، وهذا ما قاله الزبّاج. فاكتفى بالقول (استولى، عن الزبّاج) ثم فسّر معنى الاستواء بأنه الملك في قوله: "لما كان الاستواء على العرش، وهو سرير الملك مما يردف الملك جعلوه كناية عن الملك، فقالوا: استوى على العرش، أي: ملك، وإن لم يقعد على السرير البتة، ثم قال: والمذهب قول علي - رضي الله عنه -: الاستواء غير بجهول، والتكيف غير معقول، والإيمان به واجب، والسؤال عنه بدعة، لأنه - تعالى - كان ولا مكان فهو على

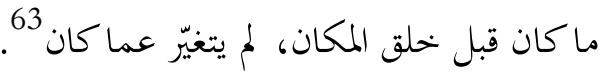
فالإمام النّسفيّ يقول بعد أن أورد معاني اللفظة: إن المذهب هو قول علي - رضي الله عنه - لا قول القاضي عبد الجبار، أو

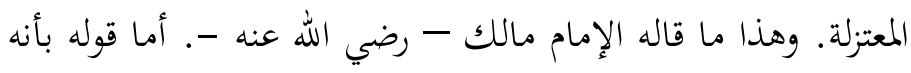
يتكلف تطويع النصوص لكي ينتصر لرأيه...، فلا أحسب الإمام كذلك واستشهاده بقول الشاعر ليس إلا توضيحاً لمعنى اللفظة، ولأن المققق نفسه يذكر أن الإمام ذكر موقفين بإزاء النصوص الموهمة للتشبيه، الأول: هو قول السلف في تصديقها وتفويض أمرها إلى الله وعدم الخوض والبحث في هذه الأمور لكن مع ملاحظة التنزيه وعدم التشبيه، والثاني: قول الخلف في تأويلها بما يليق بالله تعالى مع عدم

${ }^{63}$ Al-Nasafī, Tafsìr al- Nasafï, 2:357. 
Syed Mohammad Hilmi \& Mohd Khairul Naim, "Transcendence of Allah According to al-Zamakhshari \& al-Nasafï," Afkār Vol. 19 Issue 1 (2017):

القطع بأن التأويل هو مراد الله تعالى، ثم يقول: وقد عقب الإمام على مذهب السلف بأنه أسلم، وبأن مذهب الخلف أحكم"، ثر بـ يعود فيؤكد أن المصنف (أي الإمام) يرجح مذهب الخلف ويميل إليه 1".

غير أني أجد الإمام النّسفيّ قال: والمذهب قول علي رضي الله

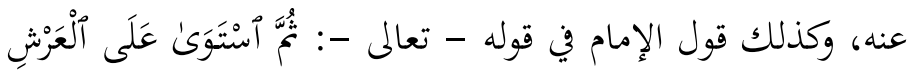
[الأعراف: ــ]، "وتفسير العرش بالسرير، والاستواء بالاستقرار كما تقوله المشبّهة باطل، لأنه - تعالى - كان قبل العرش ولا مكان، وهو الآن كما كان، لأن التغير من صفات الأكوان 65.

فبقوله هذا، وإن ذكر أن استوى بمعنى: استولى، إنما قوله لكي يخطئ قول المشبّهة، لا ليسلك فج المعتزلة، والذي يثبت هذا قوله في نفس الآية مكمّلا لها، "والمنقول عن الصادق والحسن، وأبي حنيفة، لهن ومالك - رحمهم الله - أن الاستواء معلوم، والتكييف فيه بجهول،

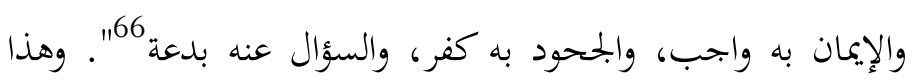
هو معنى قوله: وهو أسلم، يعني: عدم التأويل.

${ }^{64}$ Ibrāhìm, Kitāb 'Umdah al- 'Aqā'id, 58-60.

${ }_{65}^{65}$ Al-Nasafî, Tafsìr al- Nasafì, 1:573.

${ }^{66}$ Ibid. 
Syed Mohammad Hilmi \& Mohd Khairul Naim, "Transcendence of Allah According to al-Zamakhshari \& al-Nasafï," Afkār Vol. 19 Issue 1 (2017):

فالإمام النّسفيّ وإن أوّل بعض الألفاظ كما سيأتي ذكرها في

محلها، إنما أراد بذلك التدليل على مخالفة الله للحوادث، ونفي ما لا يليق به - تعالى -، ونفي مشاهته لخلقه، وتنزيه - تعالى - التنزيه الكامل عن المكان، والجهة. فتأويلات الإمام ما هي إلا ما كان ظاهراً بنفسه للجميع موافقاً للعقل والنقل والبرهان، وما لا ينكره إيمان من آمن بكلام الله على مراد الله. وعن قيامه - تعالى - بذاته وبأنه مستغن بذاته عمن سواه

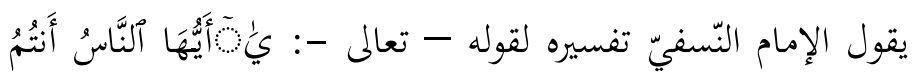

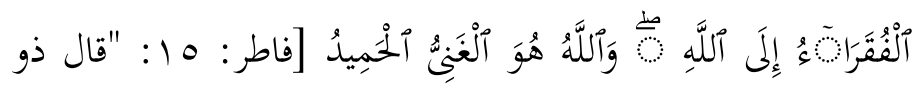
النون: الخلق محتاجون إليه في كل نفس، وخطوة، ولحظة، وكيف لا

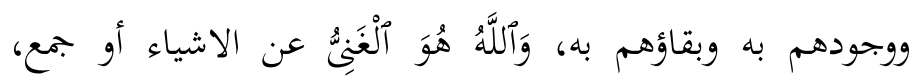

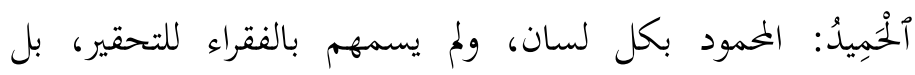
للتعريض على الاستغناء، ولهذا وصف نفسه بالغني الذي هو مطعم

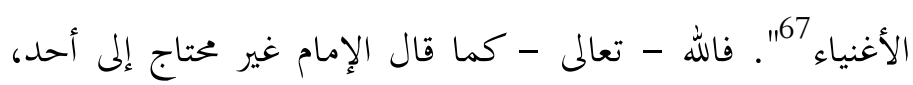

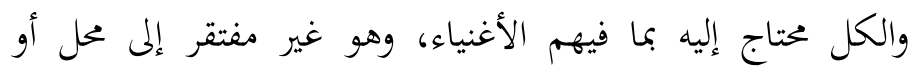
غخصّص، فهو غني عن ذلك، لأنه لو احتاج إلى مخصّص لاحتاج إلى الى مؤثر موجد، وهو - تعالى - موجود بنفسه واجب الوجود. والله -

${ }^{67} \mathrm{Ibid}$. 
Syed Mohammad Hilmi \& Mohd Khairul Naim, "Transcendence of Allah According to al-Zamakhshari \& al-Nasafï," Afkār Vol. 19 Issue 1 (2017):

تعالى - لا يفتقر إلى محل يقوم به وإلا لكان صفة لا ذاتاً. فالمخلوقات بأكملها تقوم بالله - جل وعلا -، أما هو فهو القائم بنفسه المستغني عمن سواه.

والإمام النّسفيّ ينزه الله - تعالى - عن أن يكون محتاجا إلى ميلى

أحد بل الكل محتاج إليه حين يفسر كلمة الصمد في قوله - تعالى -

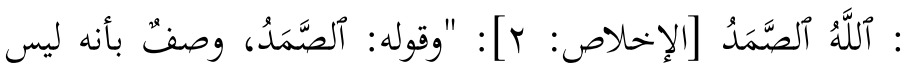

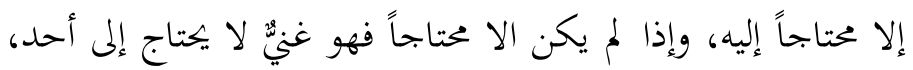

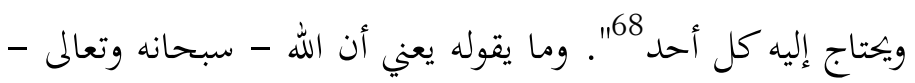
قائم بنفسه، متعال عن الافتقار إلى محل يحله، أو ما كان يقله.

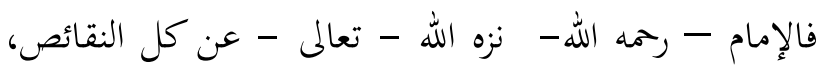
وأثبت له الاسماء الحسنى الدالة على الصّفات العلا التي لم ينفِها، فهو

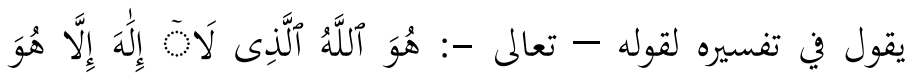

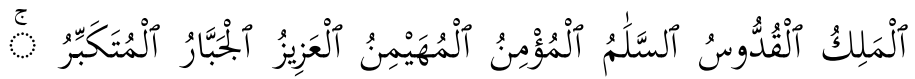

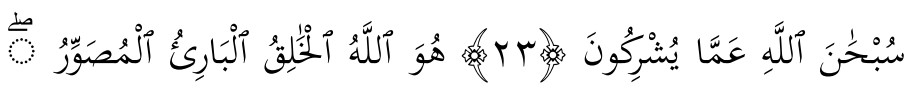

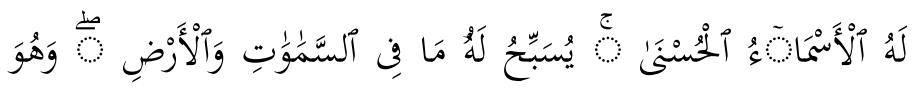

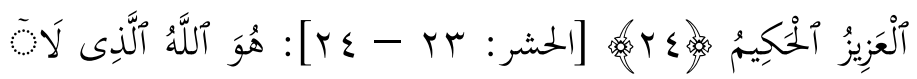

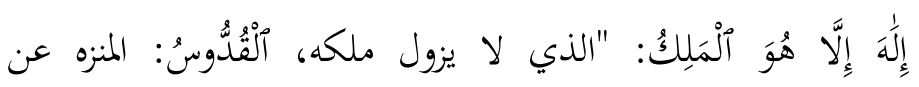

${ }^{68}$ Ibid., 3:695. 
Syed Mohammad Hilmi \& Mohd Khairul Naim, "Transcendence of Allah According to al-Zamakhshari \& al-Nasafï," Afkār Vol. 19 Issue 1 (2017):

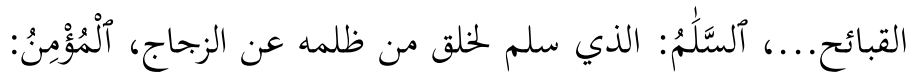
واهب الأمن، وعن الزجاج الذي آمن الخلق من ظلمه، أو المؤمن من

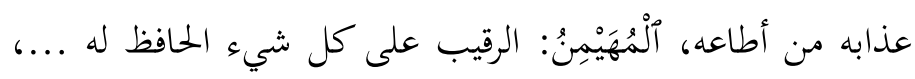

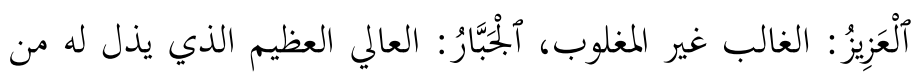
دونه، أو العظيم الشأن في القدرة والسلطان، أو القهار ذو الجبروت،

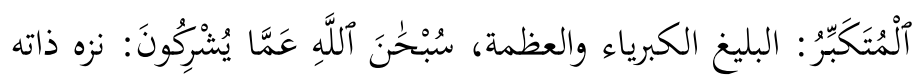

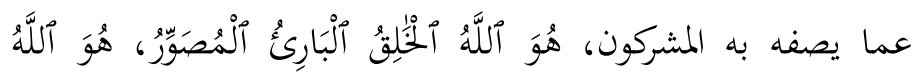

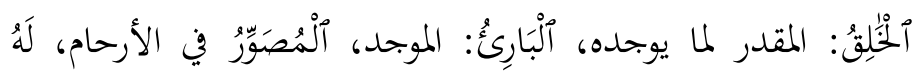

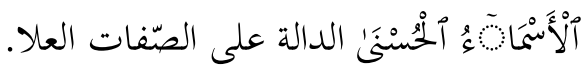
ورأيي في التنزيه أن التنزيه لفظ استخدمه الكل حين تعلق اللفظ بالذات والصفات، والتشبيه والتجسيم، والقول بأنه سلب ما لا يليق بالواجب عن الله - تعالى -، بناءً على تأويل الصّفات الخبرية، والتكلم في الوحدانيّة، والقدم، والبقاء، والمكانيّة والزمانيّة، والجهة والحيّز، والجسميّة وغيرها، فالكلمة هي: تنزيه الله عن مشابهة

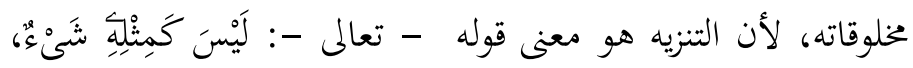

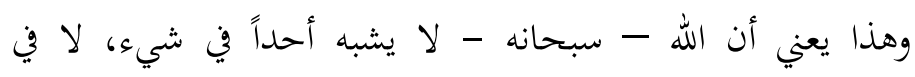
صفات، ولا أفعال، ولا ما يخطر على بال، أو يتوهمه عقل محدود يقيس الله - تعالى - على الخلق. 
Syed Mohammad Hilmi \& Mohd Khairul Naim, "Transcendence of Allah According to al-Zamakhshari \& al-Nasafï," Afkār Vol. 19 Issue 1 (2017):

فهل يعقل أن يقول مسلم ذو عقل سليم سمع القرآن بلسان عربي مبين قويم، في قوله - تعالى -: بَّلْ يَدَاهُهُ مَبُْوطَتَاِِ [المائدة: ع7]، وهو يعي أن العربية فيها الحقيقة، وفيها المحاز، والكنايات، والاستعارات، وأن اليد في اللغة لها أكثر من معنى تؤديه؛ أن لفظة اليد هنا هي الجارحة من أعضاء الجسد عند المخلوق؟ وأن اليد المبسوطة هي المنشورة كما ينشر البساط، أو على معنى نشر الأصابع

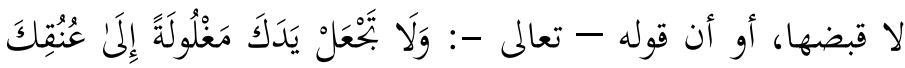

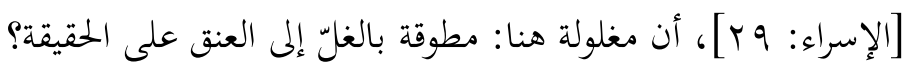
لماذا لم فهم قريش ذلك؟ بل أدركت من غير تفكير أن مبسوطة تعني: النعمة أو السخاء، وأن مغلولة تعني: البخل. فالسلف الصلح فهموا ذلك لأفم أدركوا معنى قوله - تعالى -

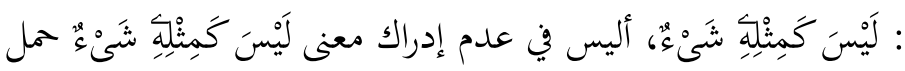
للألفاظ على ما لا يليق يجلاله -تعالى -؟ فوصف الله - تعالى وتسميته ليس إلا بما وصف هو به نفسه، وسمّاه على رسوله، أي: بما دل عليه القرآن من صفاته أو تقدم به رسوله، فعندما تكلم المتكلمون واختلفوا في فهم الألفاظ الموهمة للتشبيه، لم يكن ذلك إلا لأهم خاضوا في التأويل؛ وما نفى البعض التشبيه، وعطل البعض الصفات، وشط البعض في فهم هذه الألفاظ، مع أن الأصل هو في إثبات 
Syed Mohammad Hilmi \& Mohd Khairul Naim, "Transcendence of Allah According to al-Zamakhshari \& al-Nasafï," Afkār Vol. 19 Issue 1 (2017):

اللفظ، وتفويض المعنى المراد إلى علم الله تعالى، وإمرار الصَفات على ما جاءت من غير تفسير، ولا تأويل إلا ما يقع ضرورة كقوله - تعالى -: " وجاء ربك" أي: أمر ربك، فإثبات صفاته - تعالى - لا

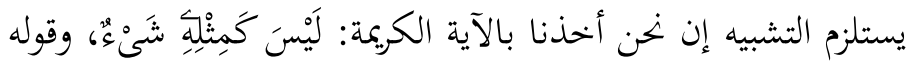

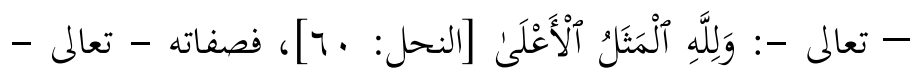
قد تنزهت عن سمات الحدوث، كما أن ذاته قد تقدّست عن أن تشبه مخلوقاته، ولا يجبوز أن ننفي صفات أوجبها القرآن وأوجبتها السنة، وحتى العقل لله - تعالى -، بل صفات الله هي صفات الكمال، وقراءها تفسيرها، من غير حاجة إلى تأويل فهي منزهة عن صفات المحدثين فيجدر الوقوف على قوله - تعالى -: وَمَا يَعْلَمُ

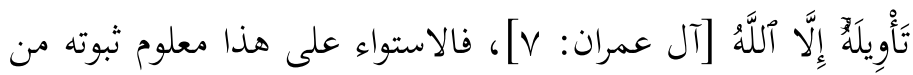
النص القرآني، وكيفه غير مقعول، لأن الله منزه عن الجسمية، والمكانية، والجهة، والحيّز، وهو القديع، ولا شريك له - تعالى -. فالتنزيه هو ما وصف الله به نفسه نفياً وإثباتاً، فلو أشبه الله الحوادث لكان حكمه في الحدث حكمها، ولو أشبها في الجهة،

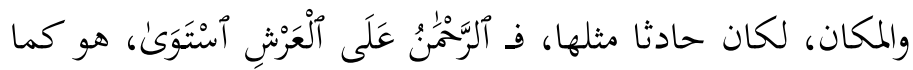
قال - تعالى -، لأنه - سبحانه - متقدس عن الاختصاص بالجهات، لا يوصف بالإثبات، والبميء، ولا القيام، ولا القعود، فهو 
Syed Mohammad Hilmi \& Mohd Khairul Naim, "Transcendence of Allah According to al-Zamakhshari \& al-Nasafï," Afkār Vol. 19 Issue 1 (2017): $163-222$

لا يشبه الخلق، وأمارة الحدوث لا تنطبق عليه. ووحدانية الله هو من أخبر عنها، فأخبرنا أنه واحد في الألوهية، حيث يقول - سبحانه -:

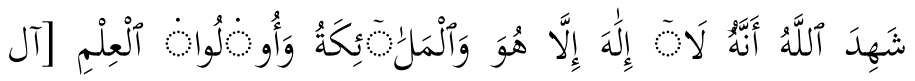

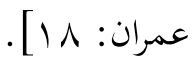

فقد نزه الله - تعالى - الإمام النّسفيّ امتثالاً لأمره، لا لتوهُم

لحوق صفات المحلث، أو الحدث به - تعالى -، ولأنه قد ثبتت له تعالى - الأسماء الحسنى، والصفات العلا، لا لنقص أو عيب، فالله له الكمال المطلق ولغيره النقص والاحتياج والآفة. لأنه - تعالى - لاي مثل له، ولا شبيه، ولا نظير، وهذه هي الحقيقة الحقة في تنزيهه تعالى - وإثبات كمال الصّفات والألوهية له، فهو الله لا سميميّ له: وَلَّْ

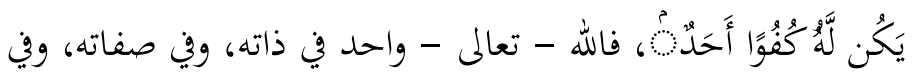
أفعاله، وقد ثبتت له صفات القدم، والبقاء، ومخالفة الحوادث، والوحدانية، والقدرة، والإرادة، وباقي الصفات، وإن اختلفت طريقة الاستدلال عند الفرق المثبتة لهذه الصّفات فلا خلاف في أن لله الكمال، والتنزيه الخالص باتفاق جميع المسلمين. لم يختلف الإمام النّسفيّ عن الإمام الزّخشريّ في تنزيه الله تعالى - فقد فسّر كل منهما الآية التي تتطلب التنزيه تفسيراً يدلّ على تقارب وجهات النظر، واختيار الكلمات المناسبة لذلك حتى في 
Syed Mohammad Hilmi \& Mohd Khairul Naim, "Transcendence of Allah According to al-Zamakhshari \& al-Nasafï," Afkār Vol. 19 Issue 1 (2017):

تفسيرها لبعض الألفاظ الموهمة للتشبيه إن كانت لا تخالف فج كل منهما كون كل منهما ينتمي إلى مذهب يفرض عليه الالتزام بمبادئ المذهب؛ فالإمام الزّخشريّ مثلاً يقدم العقل على النقل، بينما الإمام النّسفيّ وإن كان يستخدم العقل في فهم النصوص إلا أنه يقدم النقل على العقل، لأن العقل عند المعتزلة قبل كل شيء بخلاف أهل السنة، ومع هذا فهما في تفسيرها لبعض الآية كما قلت يتفقان على جوهر التنزيه.

فأرى الإمام الزّخشريّ يقول في تفسير قوله - تعالى -:

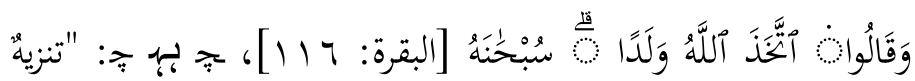
له عن ذلك وتبعيدُ 69". وتبع ما قاله الإمام النّسفيّ عند تفسيره للآية حيث يقول: سُبْحَنَهُ: "تنزيهُ له عن ذلك وتبعيدُ 70".

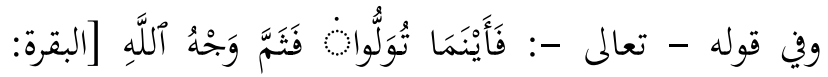
110]، يقول الإمام الزّخشريّ: فَتَََّّ وَجْهُ أللَّهَ، أي: جهته التي أمر هما ورضيها. والمعنى أنكم إذا مُنعتم أن تصلوا في المسجد الحرام، أو في بيت المقدس ، فقد جعلت لكم الأرض مسجداً فصلوا في أيّ بقعة شئتم من بقاعها، وافعلوا التولية فيها، فإن التولية ممكنة في كل مكان، لا يختص إمكانما في مسجد دون مسجد، ولا في مكان دون

${ }^{69}$ Al-Zamakhshari, al-Kashshāf , 1:207.

${ }^{70}$ Al-Nasafī, Tafsír al- Nasafīi, 1:123. 
Syed Mohammad Hilmi \& Mohd Khairul Naim, "Transcendence of Allah

According to al-Zamakhshari \& al-Nasafï," Afkār Vol. 19 Issue 1 (2017):

مكان 71، وهذا أيضا ما يقوله الإمام النّسفيّ حيث يقول: "أي: جهته التي أمر بها ورضيها، والمعنى... 72 "، فيكمل كما أكمل الإمام الزّخشريّ، ف(وجه الله) عند الإمامين بمعنى واحد، لا خلاف بينهما في أنه الجهة التي أمر بها الله، ورضيها. كما أرى الإمام النّسفيّ يقول في تفسيره لقوله - تعالى -: وَهُوَ مَعَكُمْ أَيْنَ مَا كُنتُمْ [الحديد: ع] : " بالعلم والقدرة عموما وبالفضل والرحمة خصوصا"73"، وهذا ما ذهب إليه الإمام الزّخشريّ

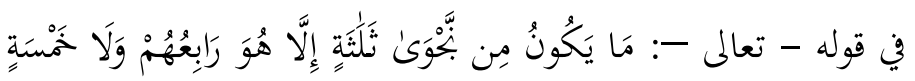

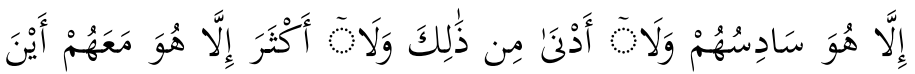
مَا كَانُوارِ [ابمحادلة:V]: "ومعنى كونه معهم: أنه يعلم ما يتناجون به، ولا يخفى عليه ما هم فيه، فكأنه مشاهدهم ومحاضرهم، وقد تعالى عن المكان والمشاهدة74". وهذا أيضا ما قاله الإمام النّسفيّ في تحسي تفسيره لمذه الآية حيث يقول: "يعلم ما يتناجون به ولا يخفى عليه ما هم فيه، وقد تعالى عن المكان علواً كبيراً 75".

\footnotetext{
${ }^{71}$ Al-Zamakhshari, al-Kashshāf, 1:206-207.

${ }^{72}$ Al-Nasafī, Tafsìr al-Nasafi, 1:123.

${ }^{73}$ Ibid.

${ }^{74}$ Al-Zamakhshari, al-Kashshāf, 4:488.

75 Al-Nasafi, Tafsír al- Nasafī, 3:447.
} 
Syed Mohammad Hilmi \& Mohd Khairul Naim, "Transcendence of Allah According to al-Zamakhshari \& al-Nasafï," Afkār Vol. 19 Issue 1 (2017):

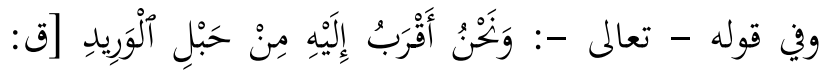

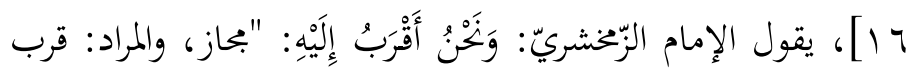

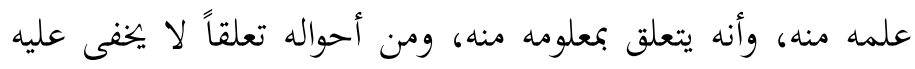
شيء من خفياته، فكأن ذاته قريبة منه، كما يقال: الله في كل مكان، لهان

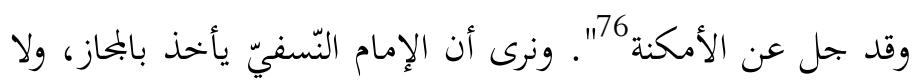
فرق بين تفسيره وتفسير الإمام الزّخشريّ حيث يقول في تفس الآية:

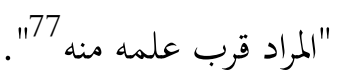

كما أرى أن لا خحلاف بين الإمامين وبين الإمام الطبري في

تفسيره لمذه الآية، فالإمام الطبري نفى القرب الحسي الذي تقول به

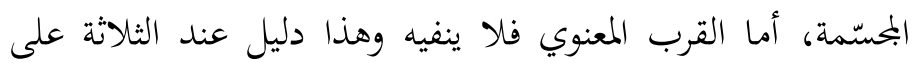
تنزيه الله عن الجهة والمكانية، حيث يقول الإمام الطبري: "فقال بعضهم: معناه: نحن أملك به، وأقرب اليه في المقدرة عليه، وقال

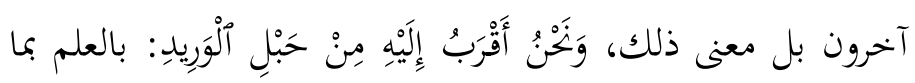

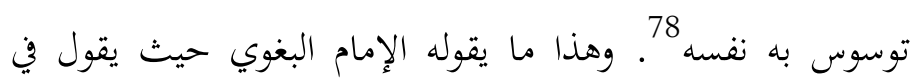

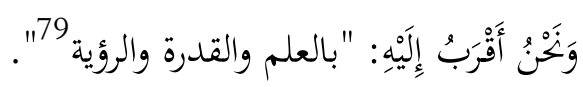

${ }^{76}$ Al-Zamakhshari, al-Kashshāf, 4:387.

77 Al-Nasafï, Tafsír al- Nasafï, 3:364.

${ }^{78}$ al-Ṭabarí, Jāmi`al-Bayān, 22:342.

79 Abū Muhammad al-Husāyn bin Mas`ūd al-Baghawī al-Shāfìi,

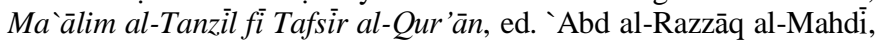
1st edition (Beirut: Dār Ihyā' al-Turāth al-`Arabī, 1420H), 5:22. 
Syed Mohammad Hilmi \& Mohd Khairul Naim, "Transcendence of Allah According to al-Zamakhshari \& al-Nasafï," Afkār Vol. 19 Issue 1 (2017): $163-222$

وقد جاء تفسير الإمامين واحداً عند تفسيرهما لقوله - تعالى -

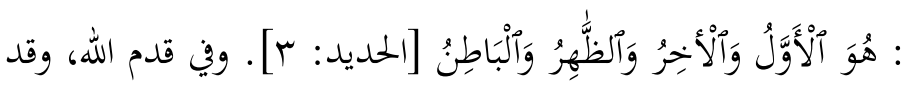
تكلمت عن هذا من قبل وفي معنى الاستواء لم ينكر الإمام النّسفيّ أها أي اللفظة تأتي بمعنى الاستيلاء. كذلك ألفاظ اليد والعين، وغيرها، ولم يختلف تفسير هذه الألفاظ لا عند الزّخشريّ، ولا

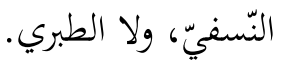
وكما تقدم في أن القول بالجوارح محال على الله، فاليمين عند العرب من معانيها القوة والقدرة على ذلك جاء تفسير الإمام الزبخشريّ

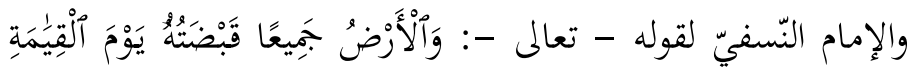

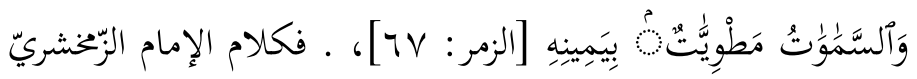
هو ما قاله الإمام النّسفيّ في تفسيره للآية. وفي تفسير الإمامين للفظه المحيء في قوله - تعالى -: وَجَاَهَ رَبُّكَ وَاْلْمَلكُ صَفَّا صَفَّا [الفجر:22]، انسجام وتوافق حيث يقول الإمام الزّخشريّ: "فإن قلت: ما معنى إسناد المحيء إلى الله، والحركة، والانتقال، إنما يجبوز على من كان في جهة؟ قلت: هو تمثيل لظهور آيات اقتداره، وتبيين آثار قهره وسلطانه، مثلت حاله في ذلك بحال 
Syed Mohammad Hilmi \& Mohd Khairul Naim, "Transcendence of Allah According to al-Zamakhshari \& al-Nasafï," Afkār Vol. 19 Issue 1 (2017):

الملك إذا حضر بنفسه ظهر بحضوره من آثار الهيبة والسياسة ما لا يظهر بحضور عساكره كلها، ووزرائه، وخواصه عن بكرة أبيهم 80. ويقول الإمام النّسفيّ: وَجَاَّهَ رَبُّكَ تمثيل لظهور آيات اقتداره، وتبيين آثار قهره وسلطانه، فإن واحداً من الملوك إذا حضر بنفسه ظهر بكضوره من آثار الهيبة ما لا يظهر بكضور عساكره

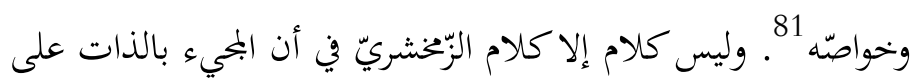
الله - تعالى - محال، لأن الذهاب، والإتيان، والبكيء، وإثبات هذه الصّفات من أمارات الحدث، وصفات الحوادث التي لا تليق بذاته -

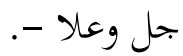
وين الوحدانيّة وباقي الصّفات لم يكن هناك كبير اختلاف بين الإمامين في إثباةتن لأن تنزيه الله - تعالى - عن كل مشابهة بخلقه وتأكيد الكمال له وحده كان مطلب المعتزلة، كما هو مطلب

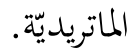
وإن أسرفت المعتزلة في تنزيهها لله - تعالى - إلا أفا كانت السابقة على غيرها من الفرق في تنزيه الله - تعالى - ردَّا على من أخلّ بالتنزيه من المشبّهة والبحسّمة. فالإمام الزّخشريّ نفى الشريك وأثبت الوحدانيّة وأبطل القول بتعدد الآلةة فالله أحد لا جزء له، وهذا ما

${ }^{80}$ Al-Zamakhshari, al-Kashshāf, 4:754-755.

${ }^{81}$ Al-Nasafī, Tafsìr al-Nasafï, 3:641. 
Syed Mohammad Hilmi \& Mohd Khairul Naim, "Transcendence of Allah According to al-Zamakhshari \& al-Nasafï," Afkār Vol. 19 Issue 1 (2017):

ذهب إليه الإمام النّسفيّ وقد بينت هذا عند الكلام في الوحدانيّة وإثبات وجود الله عند الإمامين، كما أهما نفيا المكانية وأبطلا القول بالجسميّة ونفي حلول الحوادث بذاته - تعالى - لأنه - تعالى ليس بجوهر، ولا عرض، ولا محدث، ولا يجوز عليه ذلك، كما لا بتوز عليه الجهة انطلاقاً من تنزيه الله - تعالى - لقوله - عز وجل - لَيَّنَ

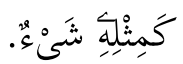
وبناءً على ما سبق، يمكني أن أقول: إنه لا خلاف عند أيِّ

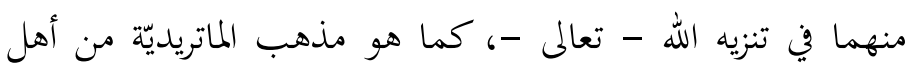
السيّة والجماعة عند الكلام في نفي النقص عن الله - تعالى وسلب ما لا يليق به - سبحانه وتعالى - وإن اختلفت الأدلة، والطرق المؤدية إلى ذلك، سوى الخلاف في ما يبنى عليه هذا التنزيه؛ فالزّخشريّ على سبيل المثال، ينزه الله - تعالى - عن الصّفات بناءً على أها لو قامت بالذات - وهي قديمة - لتعدد القدماء، وهذا ينافي مبدأ توحيد الله عنده. أما النّفيّ، وإن كان ينزه الله عن مماثلة الحوادث، ومشابكته كالزّخشريّ إلا أنه يثبت الصّفات القديمة القائمة بالذات الإلمية، وهي عنده إن كانت قديمة فلا تؤدي إلى تعدد القدماء، لأن قدم الصّفات المتعددة القائمة بالذات لا يضرّ ما دامت الذات الإلهية واحدة، لا تتعدد. 
Syed Mohammad Hilmi \& Mohd Khairul Naim, "Transcendence of Allah

According to al-Zamakhshari \& al-Nasafï," Afkār Vol. 19 Issue 1 (2017):

فالإمامان متفقان على أنه مهما تصور أحد من البشر بباله، أو وقع شيء في قلبه عن الله - تعالى -، فالله خلاف ذلك، فهو القديم، لا أوّل له، والدائم لا آخر له، لا ضد له، ولا نظير، ولا معين ولا وزير، لا تماثله الموجودات، ولا يماثلها، ولا تحويه الأزمان، ولا الجهات، ولا يحلّ فيها، ولا يحتاج إلى مكان، ولا يفتقر إلى زمان. كما أن الله - تعالى - عند هما موجود قبل الخلق، ليس له قبل، ولا بعد، ولا فوق، ولا تحت، ولا يمين، ولا شمال، ولا أمام، ولا خلف. لا يقال: متى كان، أو أين كان؟ فإنه هو الذي أيَّن الأينَ فكيف يقال له أين؟ كما لا يقال: كيف كان؟ فإنه هو الذي كيَّف الكيف، فكيف يقال له كيف؟ فالله - تعالى - كان ولا مكان، وهو الذي كوّن الأكوان، ودبّر الزمان، ولا يتقيّد بالزمان، ولا يتخصّص بالمكان، لا يلحقه وهم ولا يكيّفه عقل، لا يتشخص في الذهن، ولا يتمثل في النفس.

فالله هو الإله الواحد، لا إله إلا هو، لا شبيه له ولا مثيل، ولا كفء له لا ولد، ولا والد له ولا صاحبة. لا ابتداء له، ولا انتهاء، له الأسماء الحسنى والصفات العلا، لا تحدّه الحدود، الحيّ الذي لا يموت، ولا يضلّ ولا ينسى، ولا تدركه الأبصار. 
Syed Mohammad Hilmi \& Mohd Khairul Naim, "Transcendence of Allah

According to al-Zamakhshari \& al-Nasafï," Afkār Vol. 19 Issue 1 (2017):

\section{References}

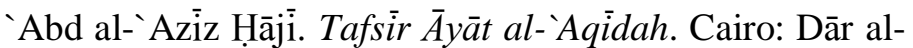
Sāaūni, 2003.

Abū Hayyān al-Andalusī, Muhammad bin Yūsuf bin `Ali. Al-Bahr al-Muhịt fì al-Tafsír, ed. Șidqi Muhammad Jamil. Beirut: Dār al-Fikr, 1420H.

Abū Muḥammad al-Andalusí al-Muhāribìi,’Abd al-Haq bin Ghālib bin 'Abd al-Raḥmān bin Tamām bin `Ațiyyah. Al-Muharrar al-Wajiz fí Tafsir al-Kitāb al-'Azíz, ed. 'Abd al-Salām `Abd al-Shāfī Muhammad, 1st edition. Beirut: Dār al-Kutub al-'Ilmiyyah, 1422H.

Al-Ash`arí, Abū al-Ḥasan 'Alì bin Ismā'ìl. Maqālāt alIslāmiyyīn wa Ikhtilāf al-Muṣallīn. Beirut: Dār Ihyyā' alTurāth al-`Arabi, n.d.

Al-Baghawi al-Shāfi' $\bar{i}$, Abū Muḥammad al-Ḥusāyn bin Mas`ūd. Ma 'àlim al-Tanzì fí Tafsìr al-Qur'ān, ed. 'Abd al-Razzāq al-Mahdì, 1st edition. Beirut: Dār Ihyā' alTurāth al-'Arabi, $1420 \mathrm{H}$.

Al-Ghāmidī, Șāliḥ bin Gharm Allāh. Al-Masā'il alI tizāliyyah fī Tafsìr al-Kashshāf li al-Zamakhshari fī Daw' mā Warad fï Kitāb al-Intișāf li Ibn al-Munayyir. Lahore: Dār al-Andalus, n.d.

Ibn `Ảdil al-Ḥanbali al-Dimashqi al-Nu mānī, Sirāj al-Dīn 'Umar bin `Alì. Al-Bāb fí 'Ulūm al-Kitāb, ed. 'Ādil Aḥmad 'Abd al-Mawjūd and 'Ali Muhammad Mu awwiḍ. Beirut: Dār al-Kutub al-`Ilmiyyah, 1998.

Ibn al-Munayyir. Al-Intișāf fimā Tadammanuhu alKashshāf min al-I tizāl (Hāshiyah ‘ala al-Kashshāf). Beirut: Dār al-Kitāb al-'Arabì, 1407H.

Ibn Kathīr al-Bașrī al-Dimashqì, Abū al-Fidā' Ismā'ìl bin 'Umar. Tafsìr al-Qur'ān al-'Azìim, ed. Sāmì bin Muḥammad Salāmah, 2nd edition. Riyadh: Dār Tayyibah, 1999.

Ibn Taymiyyah al-Harrāni, Taqi al-Dīn Abū al-`Abbās Ahmad bin `Abd al-Halīm. Majmū `al-Fatāwā, ed. `Abd 
al-Raḥman bin Muḥammad. Medina: Mujamma' alMalik Fahd li al-Ṭibā`ah al-Muṣhaf al-Sharif, 1995.

Ibrāhịm, Ibrāhīm `Abd al-Shāfî. "Kitāb 'Umdah al'Aqā'id li al-Imām Abī al-Barakāt al-Nasafīi: Dirāsah wa Taḥqiq." Master Dissertation, Faculty of Ușūl al-Dīn, University of al-Azhar, 1987.

Al-Māturìīi. Al-Tawhìid, ed. Fatḥ Allāh Khalīf. Alexandria: Dār al-Jāmi āt al-Mișriyyah, n.d.

Al-Nasafí, Abū al-Barakāt 'Abd Allāh bin Aḥmad bin Maḥmūd Hāfiz al-Dīn. Tafsìr al-Nasafī Madārik alTanzìl wa Haqā'iq al-Ta'wìl, ed. Yūsuf `Alì and Muhy al-Dīn Dỉb Mistū. Beirut: Dār al-Kalam al-Ṭayyib, 1998.

Al-Nasafī, Abū al-Ma in Maymūn. Al-Tamhìd li Qawā'id al-Tawhìd, ed. Ahmad Farid, 1st edition. Beirut: Dar alKutub al-'Ilmiyyah, 2007.

Al-Sakūni, Abū 'Alī 'Umar bin Muhammad al-Maghribī al-Mālikì. Al-Tamyiz limā Awda `hu al-Zamakhsharì min al-I tizāl fi Tafsìr al-Kitāb al-`Azìiz, ed. al-Sayyid Yūsuf Ahmad. Beirut: Dār al-Kutub al-'Ilmiyyah, 2005.

Al-Sha rāwì, Muhammad Mutawallī. Tafsìr al-Sha rāwwi al-Khawāṭir. n.p: Muțābi`Akhbār al-Yawm, 1997.

Al-Shahrastāni, Muhammad bin `Abd al-Karīm. Al-Milal wa al-Niḥal, ed. Muhammad Sayyid Kaylānī. Beirut: Dār al-Ma`rifah, 1404H.

Al-Ṭabarī, Abū Ja`far Muhammad bin Jarīr. Jāmi`alBayān 'an Ta'wīl āy al-Qur'ān, ed. 'Abd Allāh bin ‘Abd al-Muhsin al-Turki. Cairo: Dār Hijr, 2001.

Zakariyyā al-Anșārì. Hāshiyah Zakariyyā al-Anșārī alMusammāh Fath al-Ilāh al-Majīd bi Ị̇āh Sharh al'Aqā'id 'alā Sharh al-'Aqā'id al-Nasafiyyah li Sa'd alDìn al-Taftāzāni, ed. 'Urfah 'Abd al-Raḥmān al-Nādí. Kuwait: Dār al-Diyā', 2013.

Al-Zamakhsharī, Abū al-Qāsim Maḥmūd bin 'Umar alKhawārizmī. Al-Kashshāf ‘an Haqā'iq al-Tanzīl wa 
Syed Mohammad Hilmi \& Mohd Khairul Naim, "Transcendence of Allah

According to al-Zamakhshari \& al-Nasafï," Afkār Vol. 19 Issue 1 (2017):

$163-222$

'Uyūn al-Aqāwīl fī Wujūh al-Ta'wìl, ed. 'Abd al-Razzāq al-Mahdi. Beirut: Dar al-Kitāb al-`Arabi, 1407H.

Al-Zamakhsharī, Abū al-Qāsim Maḥmūd bin 'Umar. Kitāb al-Minhāj fì Ușūl al-Dīn, ed. Sābīnā. Beirut: alDār al-`Ulūm al-`Arabiyyah, n.d. 